\title{
A szikes talajok N-gazdálkodása
}

A jellemző talajtulajdonságok - termőréteg vastagsága, a szerves anyag és agyag mennyisége és minősége, a mésztartalom, kémhatás stb. - nagymértékben befolyásolják a talajok víz- és tápanyag-gazdálkodását, tápanyagszolgáltató képességét, végső soron a talajok termékenységét és a mütrágyázás hatékonyságát is behatárolják.

A talaj tápanyagtároló, -szállító és egyben a különböző (fizikai, kémiai, fiziko-kémiai és biológiai) folyamatok hatására kialakult természetes miliő, amely végső soron a növény víz- és tápanyagellátásának is alapvető forrása.

A különböző talajtípusok képződési folyamataikban és jellemző tulajdonságaiban térnek el egymástól. A különböző típusú, különböző tulajdonságokkal rendelkező szikes talajok kialakulásában a vízben oldható sók döntő szerepet játszanak. Elsősorban a Nasók, amelyek oldott állapotban, részben szilárd fázisban sók formájában, vagy ionos formában kolloidok felületén adszorbeálva találhatók. A nátrium e három formájának mennyisége, minősége és aránya szabja meg a szikes talajok alapvető tulajdonságait, a szikesedés jellegét és mértékét, végső soron termékenységét (STEFANOVITS, 1982; VÁRALLYAY, 1999; SZABOLCS, 1954, 1975).

A nátrium a növény táplálkozása szempontjából szükséges elem, nagy koncentrációban azonban káros. Az oldható Na-só-készlet - a sótartalmú talajvíz, a sós felszíni vizek - a szikesedés potenciális forrása. A nagy sótartalom késlelteti, ill. gátolhatja a magcsírázást, a növény növekedést és -fejlődést, ami a talajoldat nagy ozmotikus nyomásával függ össze. A növény vízfelvétele csökken, sőt a Na-koncentráció növekedésével le is állhat. A vízfelvétel csökkenése kiegyensúlyozatlan táplálkozást, esetenként egyes ionok esetében toxikus hatás kialakulását eredményezheti. A szikes talajokban kedvezötlen a $\mathrm{Ca}: \mathrm{K}$, a $\mathrm{Na}$ ill. Ca és a $\mathrm{Na}: \mathrm{K}$ arány. Csökken a kétértékü kationok menynyisége és nő az egyértékü kationok mennyisége a növényben. A kiegyensúlyozatlan tápanyagarány, a Na-akkumuláció hatására a sejtben kialakult specifikus ioneffektus többek között az enzimek inaktiválásához, a fehérjeszintézis visszaszorításához vezethet (MENGEL, 1976).

A szikes talajok folyadékfázisában, oldatában lévő Na-sók koncentrációja a végbemenő ionkicserélődési folyamatokon keresztül hat a növények tápelem-ellátottságára, ásványi táplálkozására.

A talaj szerves-ásványi komplexumához kötött kicserélhető Na-ionok abszolút és relatív mennyisége döntően befolyásolja a szikesedés mértékét. A kolloidrészecske nátriumban való feldúsulása a talaj fizikai tulajdonságának, a vízgazdálkodási rendszer leromlásához vezet.

A talaj a nedvesség hatására megduzzad, elfolyósodik, vízáteresztő képessége jelentősen lecsökken. Megnehezíti a víz gyökerek számára való átadását, növeli a holtvíztartalmat. Száraz állapotban a talaj erősen megkeményedik és ez nagymértékben csökkenti a gyökerek behatolásának és a tápelemek felvételének lehetőségét. 
A szikes talajok szervesanyag-tartalma a Na-sók hatására mozgékonnyá válhat. A humuszos szint elfolyósodó anyaga (a Na-humát) a mélyebb talajrétegekbe hatol. A szikes talajok tápanyag-ellátottsága, tápanyagszolgáltató képessége a talajok típusától függően eltérő és a meglévő humusz- és tápanyagtőkéjük a rossz vízgazdálkodás következtében nem hasznosul kellően.

Szikes talajokban változás mutatkozik a növények N-metabolizmusában, ammónia halmozódik fel és nő a szabad aminosavak mennyisége. A nagy szódatartalom klorózist okozhat. A növények sóérzékenysége/sótoleranciája változó, többek között függ a szikes talajok típusától, az időjárási viszonyoktól, a termeléstechnológiától és nem utolsósorban a növény fejlődési szakaszától. A kérdéssel összefüggően különösen fontos a sótürő növények szelektálása, a növények sós viszonyok között történő adaptálása.

Közismert, hogy a szikesedés időszakos vízborítottsággal jár együtt, amely oxigénhiányt okoz. Növekszik a $\mathrm{CO}_{2}$ mennyisége, amely elsősorban a növény gyökerének a morfológiájára hat, ezáltal befolyásolja a növény élettani folyamatait.

A szikes talajok javításának alapvető célja a kicserélhető Na-ion mennyiségének csökkentése kémiai javítóanyagok felhasználásával. A javító anyagok milyenségét és mennyiségét a szikes talajok típusától függően kell megválasztani. Kémiai szempontból annál eredményesebb, minél jobban oldódik a felhasznált Ca-tartalmú javítóanyag.

Az öntözés hatására a sóforgalom megváltozásával és a növény jobb vízellátásával pozitív hatás mutatható ki. A szikesekhez alkalmazkodó agrotechnika egyik fontos láncszeme a talajmüvelés, amelynek kiválasztása a szikesek adottságaihoz - B-szint altalajlazítás stb. - nagyban elősegítheti a termelés eredményességét, a szikesek javításának lehetőségét. A sótürő növények a megfelelő hozam elérése mellett kedvezően hatnak a talajra, a talajban lejátszódó folyamatokra.

Szikes talajokon a vízellátással egy időben fontos a növények tápelemellátása is. Az istállótrágya és egyéb szerves trágyák a tápelem-hatásokon túlmenően a talajlazítás és a különböző talajtulajdonságokra kifejtett hatások kedvezően befolyásolják a szikesek hasznosítását (ÁBRAHÁM \& BOCSKAI, 1971; Herke, Prettenhoffer, Harmati, Gratzl, Darab In: A szikes talajok ...., 1966; BLASKÓ, 1999).

A szikesek tápanyagtőkéje eltérő, estenként csekély. Jellemző viszont, hogy a meglévő tápanyagforrás hasznosítását a szikesek termékenységét gátló tényezők (nagy sótartalom, rossz fizikai, kémiai tulajdonság stb.) nagymértékben befolyásolják. Különösen vonatkozik ez a növények egyik legfontosabb tápelemére, a nitrogénre. Köztudott, hogy talajainkban - beleértve a szikeseket is - a növények számára felvehető formában lévő N-mennyiség csekély és szezonális változása eltérő. A talajok természetes N-ellátottságának pótlása a talajok szerves anyagának ásványosodása során történik, amelyet a szikesek kedvezőtlen tulajdonságai kedvezőtlen irányban befolyásolják. Ezzel összefüggően tehát érthető a szikes talajokon termesztett növények N-ellátásának fontos szerepe. Erről adnak számot az irodalomban megtalálható több évtized óta végzett kutatási eredmények.

A talajban lévő és a bejuttatott N-tápelemek a talajban lejátszódó folyamatok aktív részesei. A jellegzetes talajtulajdonságok hatásai és kölcsönhatásai végső soron a Ntápelem átalakulási folyamataiban visszatükröződnek és lehetőséget adnak esetenként összefüggések megállapítására, törvényszerüségek feltárására is.

A fentiekből kitűnik, hogy a N-trágyázás hatékonyságát a talajba adott N-tápelem átalakulási folyamatainak, a $\mathrm{N}$ transzformációjának mértéke és iránya szabja meg, azaz a talajba adott N-tápelem milyen mértékben marad a növény számára felvehető formá- 
ban, mennyire képes a növényt N-nel ellátni a tenyészidő alatt. Csak a fentiek ismeretében van lehetőségünk a N-mütrágyák hatékonyságának elörejelzésére, olyan trágyázásinövénytáplálási módszerek kidolgozására, amelyek alkalmazása során a talaj termékenységének fenntartásával - a környezet $\mathrm{N}$-terhelése nélkül - megfelelő hatékonyságot érhetünk el (LATKOVICS, 1988; NÉMETH, 1996).

E bevezető gondolatokhoz kapcsolódva próbálom meg kiemelni, rendszerezni és értékelni a több évtizedes kutatómunkánk során kapott eredményekből azokat, amelyeket jellegzetes hazai szikes talajokon értünk el. A kísérleteket nem ismertetem, mivel részletes leírásuk az esetek többségében az irodalomjegyzékben megadott közleményekben megtalálhatók (MÁTÉ \& LATKOVICS, 1968; LATKOVICSNÉ (1965a,b, 1966, 1974a,b, 1977, 1981, 1982, 1991), LATKOVICS \& MÁTÉ, 1968; LATKOVICS et al., 1972; LATKOVICS \& SZABOLCS, 1980; SARKADI et al., 1969; SZABOLCS \& LATKOVICSNÉ, 1967).

\section{A szikes talajok $\mathrm{N}$-ellátottsága}

Mivel kevés adat állt rendelkezésünkre szikes talajaink N-készlete, ill. a növénytáplálkozás szempontjából fontos $\mathrm{N}$-formák mennyiségének becslésére, fontosnak tartottuk néhány vizsgálat elvégzését.

Mélyben karbonátos kérges réti szolonyec (Cegléd 7. szelvény) és mélyben humuszos rétegü szolonyeces réti talaj (Cegléd 5. szelvény) légszáraz talajmintáiban vizsgáltuk az összes-N és ásványi-N mennyiségének megoszlását és változását a mintavételi idő függvényében (1. táblázat) A mintákat az MTA TAKI Szikkutatási Osztálya biztosította.

A mélyben karbonátos kérges réti szolonyec talaj összes-N-tartalma $30 \mathrm{~cm}$-ig 1155 $1717 \mathrm{mg} \mathrm{N} / \mathrm{kg}$ talaj. Ez az érték a talajszelvény mélységével csökken és $140 \mathrm{~cm}$-nél mindössze $119 \mathrm{mg} \mathrm{N}$. Az $\mathrm{NH}_{4}-\mathrm{N}$ ill. $\mathrm{NO}_{3}-\mathrm{N}$ mennyiségei közel azonosak. Összegük a felső humuszos rétegben $\sim 10 \mathrm{mg} \mathrm{N} / \mathrm{kg}$ talaj, amely az összes-N-nek $0,65 \%$-a. A szelvény mélységével az ásványi-N mennyisége egy kevéssel csökken, viszont az alsó talajréteg összes-N-tartalmához viszonyított értéke növekszik.

Ha összevetjük ugyanezen talajszelvény tavaszi és öszi mintavétel vizsgálatainak eredményeit, kimutatható, hogy az októberi minták ásványi-N-tartalma - a felső humuszos talajréteget kivéve - az áprilisban mért értékekhez viszonyítva mintegy felére csökkent. Feltehetően a növényzet ill. a talajban élő mikroszervezetek hasznosították a talaj ásványi-N mennyiségét. $\mathrm{A} \mathrm{NO}_{3}$-N lefelé történő mozgására adataink nem utalnak.

A mélyen humuszos rétegü szolonyeces réti talaj (Cegléd 5. szelvény) összes-N-tartalma a humuszos réteg mélységével összefüggően változott. $70 \mathrm{~cm}$-ig az összes-Nmennyiség $1000 \mathrm{mg} \mathrm{N} / \mathrm{kg}$ talaj feletti értéket mutat. Természetesen a felső $(30 \mathrm{~cm}$-es) talajréteg N-mennyisége a szerves anyag mennyiségével összefüggően elérte a 1826$1917 \mathrm{mg}$ értéket. $70 \mathrm{~cm}$-től a talajszelvény mélységével az összes-N-mennyiség folyamatosan csökkent, bár még a $140 \mathrm{~cm}$-es rétegben is a mért érték kétszerese a mélyben karbonátos kérges réti szolonyec talaj $\mathrm{N}$-tartalmának. $\mathrm{Az} \mathrm{NH}_{4}-\mathrm{N}$ mennyisége a $30 \mathrm{~cm}$-es talajrétegben $8,3-9,5 \mathrm{mg} \mathrm{N} / \mathrm{kg}$ talaj, a következö talajszintekben kisebb mennyiségben található $(5,0-6,0 \mathrm{mg} \mathrm{N})$ és lényegében nem változik. $\mathrm{A} \mathrm{NO}_{3}-\mathrm{N}$ mozgékonyságára utal, hogy a talajszelvényben az anyagmozgással összefüggően különböző szintekben eltérö mennyiségben jelenik meg. A felső $30 \mathrm{~cm}$-es talajrétegben közel $10 \mathrm{mg} / \mathrm{kg}$ talaj $\mathrm{NO}_{3}-\mathrm{N}$ értéket mértünk, azt követően egy kevéssel csökken, majd $80 \mathrm{~cm}$ után egy folyamatosan 


\section{1. táblázat}

Az összes-N- és ásványi-N-mennyiség megoszlása a mélyben karbonátos kérges réti szolonyec (Cegléd 7.) és a mélyben humuszos rétegü szolonyeces réti talaj (Cegléd 5.) szelvényében (LATKOVICSNÉ, 1982)

\begin{tabular}{|c|c|c|c|c|c|c|c|c|}
\hline \multirow{3}{*}{$\begin{array}{c}\text { Talaj- } \\
\text { mintavétel } \\
\text { mélysége, } \\
\text { cm }\end{array}$} & \multicolumn{5}{|c|}{ 1977. április 15.} & \multicolumn{3}{|c|}{ 1977. október 6.} \\
\hline & $\begin{array}{c}\text { Összes- } \\
\mathbf{N}\end{array}$ & $\mathrm{NH}_{4}-\mathrm{N}$ & $\mathrm{NO}_{3}-\mathrm{N}$ & $\begin{array}{c}\mathrm{NH}_{4}-\mathrm{N}+ \\
\mathrm{NO}_{3}-\mathrm{N}\end{array}$ & \multirow{2}{*}{$\begin{array}{c}\begin{array}{c}\text { Ásványi-N } \\
\text { az összes-N } \\
\text { \%-ában }\end{array} \\
\end{array}$} & $\mathrm{NH}_{4}-\mathrm{N}$ & $\mathrm{NO}_{3}-\mathrm{N}$ & $\begin{array}{c}\mathrm{NH}_{4}-\mathrm{N}+ \\
\mathrm{NO}_{3}-\mathrm{N}\end{array}$ \\
\hline & \multicolumn{4}{|c|}{ mg N/kg talaj } & & \multicolumn{3}{|c|}{ mg N/kg talaj } \\
\hline \multicolumn{9}{|c|}{ Cegléd, 7. szelvény } \\
\hline $0-10$ & 1717 & 6,2 & 5,0 & 11,2 & 0,65 & 5,5 & 6,5 & 12,1 \\
\hline $10-20$ & 1534 & 4,5 & 5,4 & 9,9 & 0,65 & 3,3 & 4,9 & 8,1 \\
\hline $20-30$ & 1155 & 5,0 & 5,0 & 10,0 & 0,87 & 2,2 & 4,2 & 6,4 \\
\hline $30-40$ & 793 & 4,5 & 4,1 & 8,6 & 1,03 & 2,4 & 5,8 & 8,2 \\
\hline $40-50$ & 441 & 4,1 & 4,1 & 8,2 & 1,86 & 2,4 & 3,7 & 6,1 \\
\hline $50-60$ & 299 & 3,7 & 4,1 & 7,8 & 2,61 & 2,6 & 4,1 & 6,7 \\
\hline $60-70$ & 329 & 4,5 & 4,5 & 9,0 & 2,74 & 2,2 & 3,0 & 5,2 \\
\hline $70-80$ & 224 & 5,0 & 4,1 & 9,1 & 4,06 & 3,0 & 2,6 & 5,6 \\
\hline $80-90$ & 165 & 4,5 & 4,1 & 8,6 & 5,21 & 1,8 & 1,8 & 3,6 \\
\hline $90-100$ & 119 & 4,1 & 4,8 & 8,9 & 7,48 & 2,2 & 2,6 & 4,8 \\
\hline $100-110$ & 127 & 4,5 & 4,1 & 8,6 & 6,77 & - & - & - \\
\hline $110-120$ & 127 & 3,7 & 4,1 & 7,8 & 6,14 & 2,2 & 2,2 & 4,4 \\
\hline $120-130$ & 134 & 4,1 & 4,1 & 8,2 & 6,12 & - & - & - \\
\hline $130-140$ & 119 & 4,5 & 3,7 & 8,2 & 6,89 & 2,2 & 2,2 & 4,4 \\
\hline \multicolumn{9}{|c|}{ Cegléd, 5. szelvény } \\
\hline $0-10$ & 1917 & 9,5 & 9,3 & 18,8 & 0,98 & 4,1 & 19,4 & 23,5 \\
\hline $10-20$ & 1841 & 8,3 & 8,1 & 16,4 & 0,89 & - & - & - \\
\hline $20-30$ & 1826 & 9,5 & 10,3 & 19,8 & 1,08 & 4,5 & 23,9 & 28,4 \\
\hline $30-40$ & 1223 & 6,6 & 6,6 & 13,2 & 1,08 & 3,3 & 13,8 & 17,1 \\
\hline $40-50$ & 1261 & 5,4 & 7,0 & 12,4 & 0,98 & 3,3 & 14,9 & 18,2 \\
\hline $50-60$ & 1212 & 5,8 & 7,6 & 13,4 & 1,11 & 2,6 & 18,6 & 21,2 \\
\hline $60-70$ & 1040 & 5,2 & 7,6 & 12,8 & 1,23 & 3,0 & 34,7 & 37,7 \\
\hline $70-80$ & 883 & 5,0 & 12,0 & 17,0 & 1,93 & 3,7 & 43,2 & 46,9 \\
\hline $80-90$ & 715 & 5,8 & 25,6 & 31,4 & 4,39 & 2,2 & 34,3 & 36,5 \\
\hline $90-100$ & 528 & 6,2 & 34,3 & 40,5 & 7,67 & 1,5 & 21,2 & 22,7 \\
\hline $100-110$ & 314 & 5,8 & 30,2 & 36,0 & 11,47 & 3,3 & 22,3 & 25,6 \\
\hline $110-120$ & 239 & 5,8 & 22,3 & 27,3 & 11,42 & 3,3 & 14,9 & 18,2 \\
\hline $120-130$ & 274 & 5,0 & 15,7 & 20,7 & 7,55 & 2,2 & 13,8 & 16,0 \\
\hline $130-140$ & 209 & 4,8 & 11,6 & 16,4 & 7,85 & 1,8 & 9,3 & 11,1 \\
\hline
\end{tabular}

növekvő felhalmozódási szint mutatkozik, amelynek legnagyobb értékeit (30,2-34,3 $\mathrm{NO}_{3}-\mathrm{N}$ ) a $100-110 \mathrm{~cm}$-es talajrétegben mérhető.

A termékenyebb, mélyen humuszos rétegủ szolonyeces réti talaj ásványi-N-tartalma valamennyi esetben felülmúlta a 10 mg-ot, sőt a felhalmozódási szintben elérte a 3640,5 mg értéket, $\mathrm{s}$ természetesen az összes-N \%-ában kifejezett értékek is magasabbak.

Az októberi talajmintákban a $\mathrm{NH}_{4}-\mathrm{N}$-tartalom kevesebb volt mint áprilisban. $\mathrm{A} \mathrm{NO}_{3}$ $\mathrm{N}$-mennyiség viszont elsősorban a felsőbb talajrétegekben több volt, amely a szerves anyag ásványosodására és a nitrifikációs folyamatokra kedvezően ható tényezők hatásával magyarázható. Az adatok azt is igazolják, hogy a $\mathrm{NO}_{3}$-felhalmozódási szint feltehetően a felfelé irányuló vízmozgás hatására mintegy $20 \mathrm{~cm}$-rel feljebb került. 


\section{Érleléses modellkísérletek}

Gázalakú $\mathrm{NH}_{3}$-veszteség és a talaj ásványi-N-tartalmának változása a kezelések hatására

A ${ }^{15} \mathrm{~N}$-jelzett vegyületek transzformációjának tanulmányozása során vizsgáltuk a talajba adott $\mathrm{N}$-vegyületekből származó gázalakú $\mathrm{NH}_{3}$-veszteséget és a talaj ásványi-N mennyiségének változását. $\mathrm{Az} \mathrm{NH}_{3}$ elillanása szoros összefüggést mutat a talaj jellemző tulajdonságaival, a környezeti tényezőkkel stb. $\mathrm{Az} \mathrm{NH}_{3}$ párolgását befolyásoló tényezők hatásának, a folyamat mechanizmusának megismerése lehetőséget biztosít az adott viszonyok között legjobban érvényesülő $\mathrm{N}$-vegyületek alkalmazására a párolgási $\mathrm{NH}_{3}$ veszteség csökkentése érdekében.

Bizonyított, hogy a talaj pH-értékének növekedésével nő az $\mathrm{NH}_{3}$-veszteség. A hőmérséklet növelése szintén az $\mathrm{NH}_{3}$ párolgását segíti elő. A gázalakú $\mathrm{NH}_{3}$-veszteség mértékét jelentősen befolyásolja továbbá a talaj kationkicserélő képessége, szervesanyag-tartalma stb. Általában semleges, vagy alkalikus talajokon $\mathrm{NH}_{4}-\mathrm{N}-\mathrm{t}$ tartalmazó trágya adagolása esetén számíthatunk $\mathrm{NH}_{3}$-veszteségre.

A karbonátos talajok felszínére adott ammóniumsók a mésszel reakcióba lépnek és ammónium-karbonát képződik. Ez a vegyület labilis, és további bomlása a reakció során

\section{2. táblázat}

A N-mútrágyák átalakulása és a különböző $\mathrm{N}$-formák változása az idő függvényében (érleléses modellkísérlet, szoloncsákos szolonyec talaj) (LATKOVICSNÉ, 1982)

\begin{tabular}{|c|c|c|c|c|c|c|}
\hline \multirow[t]{2}{*}{$\begin{array}{l}\text { Mintavétel, } \\
\text { nap }\end{array}$} & $\mathrm{NH}_{4}-\mathrm{N}$ & $\mathrm{NO}_{3}-\mathrm{N}$ & $\begin{array}{l}\mathrm{NH}_{4}-\mathrm{N}+ \\
\mathrm{NO}_{3}-\mathrm{N} \\
\end{array}$ & $\mathrm{NH}_{4}-\mathrm{N}$ & $\mathrm{NO}_{3}-\mathrm{N}$ & $\begin{array}{l}\mathrm{NH}_{4}-\mathrm{N} \\
\mathrm{NO}_{3}-\mathrm{N} \\
\end{array}$ \\
\hline & \multicolumn{3}{|c|}{ mg N/kg talaj } & \multicolumn{3}{|c|}{ az adott $N$ százalékában } \\
\hline \multicolumn{7}{|c|}{$\mathrm{Ca}\left({ }^{15} \mathrm{NO}_{3}\right)_{2}$} \\
\hline 2 & - & 582 & 582,0 & - & 96,6 & 96,6 \\
\hline 6 & 6,4 & 584 & 590,4 & 1,0 & 96,3 & 97,8 \\
\hline 11 & 5,7 & 592 & 597,7 & 0,9 & 98,2 & 99,1 \\
\hline 20 & - & 588 & 588,0 & - & 97,6 & 97,6 \\
\hline 26 & 17,5 & 573 & 590,5 & 2,9 & 95,0 & 97,9 \\
\hline 33 & 17,5 & 564 & 581,5 & 2,9 & 93,5 & 96,4 \\
\hline 40 & 11,1 & 565 & 576,1 & 1,8 & 93,7 & 95,5 \\
\hline 47 & 31,7 & 552 & 583,7 & 5,2 & 91,6 & 96,8 \\
\hline
\end{tabular}

\begin{tabular}{|c|c|c|c|c|c|c|c|c|}
\hline \multirow{2}{*}{$\begin{array}{l}\text { Minta- } \\
\text { vétel, } \\
\text { nap }\end{array}$} & $\mathrm{NH}_{4}-\mathrm{N}$ & $\mathrm{NO}_{3}-\mathrm{N}$ & $\mathrm{CO}\left(\mathrm{NH}_{2}\right)_{2}$ & $\sum \mathbf{N}$ & $\mathrm{NH}_{4}-\mathrm{N}$ & $\mathrm{NO}_{3}-\mathrm{N}$ & $\mathrm{CO}\left(\mathrm{NH}_{2}\right)_{2}$ & $\sum \mathbf{N}$ \\
\hline & \multicolumn{4}{|c|}{ mg N/kg talaj } & \multicolumn{4}{|c|}{ az adott N százalékában } \\
\hline \multicolumn{9}{|c|}{$\mathrm{CO}\left({ }^{15} \mathrm{NH}_{2}\right)_{2}$} \\
\hline 1 & 260 & 5,2 & 184,9 & 450,1 & 52,1 & 1,0 & 37,0 & 90,1 \\
\hline 2 & 329 & 1,8 & 11,9 & 342,7 & 65,9 & 0,4 & 3,4 & 69,7 \\
\hline 3 & 285 & 6,1 & - & 291,1 & 57,2 & 1,2 & - & 58,4 \\
\hline 4 & 234 & 0,5 & - & 234,5 & 47,0 & 0,1 & - & 47,1 \\
\hline 7 & 165 & - & - & 165,0 & 33,2 & - & - & 33,2 \\
\hline 11 & 128 & - & - & 128,0 & 25,8 & - & - & 25,8 \\
\hline 18 & 83 & - & - & 83,0 & 16,7 & - & - & 16,7 \\
\hline $\mathrm{SzD}_{5 \%}$ & 5 & & 11,9 & & 1,1 & & 2,3 & \\
\hline
\end{tabular}


az ammónium-karbonáttal egy időben keletkezett vegyület mennyiségétől és annak oldékonyságától függ.

Érleléses modellkísérlet-sorozatban szoloncsákos szolonyec talajon (Kunszentmiklós) - $\mathrm{pH}$ 9,3, humusz 1,3\% - a gázalakú $\mathrm{NH}_{3}$-veszteség szoros összefüggést mutatott a talajba adott $\mathrm{N}$-formákkal, a talajban történő átalakulási folyamataikkal (2. táblázat).

A Ca $\left({ }^{15} \mathrm{NO}_{3}\right)_{2}$-kezelésben gázalakú $\mathrm{NH}_{3}$-veszteség - mint várható - nem volt kimutatható, a talaj $\mathrm{NO}_{3}$-tartalma az adott $\mathrm{N}$ mennyiségével arányosan növekedett és az érlelés alatt lényegében nem változott. A 47. napon a $\mathrm{Ca}\left({ }^{15} \mathrm{NO}_{3}\right)_{2}$ nitrogénjének $91,6 \%$-a maradt $\mathrm{NO}_{3}$-formában.

Optimális hő- és nedvességviszonyok között a karbamid gyors hidrolízisére mutat, hogy már az első mintavételnél a talajba kevert karbamidnak mindössze $37 \%$-a maradt $\mathrm{CO}\left({ }^{15} \mathrm{NH}_{2}\right)_{2}$ formában. Elenyésző volt a gázalakú $\mathrm{NH}_{3}$-veszteség és a $\mathrm{NO}_{3}-\mathrm{N}$ mennyisége. A második mintavételi napon mindössze 3,4\% karbamid-N-t határoztunk meg. Nagymértékben nőtt viszont a talaj kicserélhetö $\mathrm{NH}_{4}-\mathrm{N}$ mennyisége, elérte a talajhoz adott $\mathrm{N}$-mennyiség maximumát $(65,9 \%)$. Továbbra is csekély maradt a talaj $\mathrm{NO}_{3}-\mathrm{N}$ tartalma, viszont jelentősen megnőtt a gázalakú $\mathrm{NH}_{3}$-veszteség. Az érlelés további szakaszában a karbamid transzformációjának menetét a talajban lévő kicserélhető $\mathrm{NH}_{4}-\mathrm{N}$ és a gázalakú $\mathrm{NH}_{3}$-veszteség mennyisége, és ezek ellentétes irányba történő változása jellemezte. A karbamidhoz hasonló tendencia volt megfigyelhető a talajhoz adott ammónium-szulfát transzformációja folyamán is.

A kísérlet befejezésekor - a 18. napon - a karbamid-N 16,7 \%-a maradt kicserélhető $\mathrm{NH}_{4}$-N-formában. A gázalakú $\mathrm{NH}_{3}$-veszteség elérte a 41,8 mg N-t (az adott összes-N $74,7 \%$-át). Az izotóparány-mérések eredményei igazolták, hogy a $\mathrm{NH}_{3}$-veszteség 80,491,6 \%-a az adott jelzett N-vegyületből származott.

Az adatok meggyőzően igazolták, hogy optimális nedvesség- és hőmérsékleti viszonyok között a karbamid hidrolízise gyorsan végbement. Ez bizonyos mértékig szemben áll azzal az elfogadott véleménnyel, miszerint a karbamid lebomlását, az ureáz-enzim aktivitását a magas pH és a szikes talajokban lévő szulfát- és kloridionok gátolják (LATKOVICSNÉ, 1982). Ugyanakkor igazolt, hogy a szoloncsák szolonyec talaj kedvezőtlen tulajdonságai a nitrifikációs folyamatra kifejtett negatív hatással gátolják a $\mathrm{NO}_{3}-\mathrm{N}$ képződését.

Az érlelés befejezése után vetett rozs elemzési adatai szerint a kéthetes növények Ntartalmának 24-27 \%-a kalcium-nitrátból, ill. karbamid esetében 7,3\%-a származott a hozzáadott N-vegyületekből.

$A^{15} \mathrm{NH}_{4}{ }^{15} \mathrm{NO}_{3}$ átalakulása és a szerves anyag ásványosodása két szikes talajon

A növénytermesztés során talajba kerülő szervesanyag-maradvány hatással van a talajban lejátszódó folyamatokra, a talajtulajdonságokra, többek között a talaj N-szolgáltató képességére. A talajban lévő szervesanyag-maradvány mineralizációja során felszabaduló ásványi-N növeli a talaj „felvehető" $\mathrm{N}$ mennyiségét, ezáltal részt vesz a növények és a talajban élő mikro- és makroszervezetek N-ellátásában.

A szerves anyag ásványosodásának tanulmányozására beállított érleléses modellkísérlethez 9,48 pH-jú, $1 \%$ humuszt tartalmazó meszes dunai öntéstalajon képződött szoloncsák talajt (Apaj), valamint 5,8 pH-jú, 4,8 \% humusztartalmú, gyengén szologyosodott sztyeppesedő réti szolonyec talajt (Szentistván) használtunk. A kezeléseknek megfelelően a kísérletben $\sim 300 \mathrm{mg} \mathrm{N} / \mathrm{kg}$ talaj adagnak megfelelö ${ }^{15} \mathrm{NH}_{4}{ }^{15} \mathrm{NO}_{3}$ vegyü- 
letet adtunk, szerves anyagnak $3 \%$-os ${ }^{15} \mathrm{~N}$-tartalmú ledarált babszárat alkalmaztunk a bemért talajmennyiség 0,4\%-ának megfelelő mennyiségben. Az érlelés során vizsgáltuk az ${ }^{15} \mathrm{NH}_{4}{ }^{15} \mathrm{NO}_{3}$ transzformációját a talajban, a ${ }^{15} \mathrm{~N}$-jelzett szerves anyag ásványosodásának a mértékét, valamint az ammónium-nitrátnak a szerves anyag mineralizációjára kifejtett hatását.

Az érlelés alatt vett talajminták $\mathrm{NO}_{3}-\mathrm{N}$ és kicserélhető $\mathrm{NH}_{4}-\mathrm{N}$-tartalmának változása jól nyomon követhető volt. Az érlelés folyamán a kezelésben nem részesült talajok ásványi-N-tartalma nőtt. A legnagyobb értéket a 63. napon mértük, ezt követően egy kevéssel csökkent, és az utolsó (88.) napon a két talajon közel azonos értéket (58-59 mg N) kaptunk.

Az eltérő nitrifikációs folyamatokra utal, hogy a gyengén szologyosodott sztyeppesedő réti szolonyec talajon az ásványi-N-mennyiség nagyobb részét már az érlelés kezdetén is a nitrát képezte, míg a szoloncsák talajon a nitrát csak az inkubáció későbbi szakaszában jelent meg.

Az ammónium-nitrát hatására mindkét talaj ásványi-N-tartalma a $\mathrm{N}$-adaggal arányos volt. Szoloncsák talajon a $\mathrm{NO}_{3}-\mathrm{N}$ és $\mathrm{NH}_{4}-\mathrm{N}$ mennyisége az érlelés során 63 napig lényegesen nem változott, a talaj magas $\mathrm{pH}$-értéke és sókoncentrációja gátolta a nitrifikáló baktériumok tevékenységét. A 88. napon mért értékek viszont kismértékben nitrifikációra utalnak, ugyanakkor az ásványi-N-mennyiségben csökkenés figyelhető meg.

A gyengén szologyosodott sztyeppesedő réti szolonyec talajon optimális viszonyok között igen szembetünő a nitrifikációs folyamat. Az érlelés során a $\mathrm{NO}_{3}$-tartalom növekedésével összefüggően jelentősen csökkent az $\mathrm{NH}_{4}-\mathrm{N}$ mennyisége és az előző talajon kapott eredményekhez hasonlóan csökkent a kimutatható ásványi-N mennyisége. A talajhoz adott ${ }^{15} \mathrm{~N}$ szerves anyag ásványosodásának üteme és mértéke, a mineralizáció során képződött $\mathrm{NH}_{4}-\mathrm{N}$ és $\mathrm{NO}_{3}-\mathrm{N}$ mennyisége a két vizsgált talajon szintén eltérő volt. Szoloncsák talajon a szerves anyag ásványosodása során képződött $\mathrm{NH}_{4}-\mathrm{N}$ mennyisége a 35. napig fokozatosan növekedett, majd ezt követően a nitrifikáció hatására csökkent. A gyengén szologyosodott sztyeppesedő réti szolonyec talaj kedvezőbb feltételeket biztosított a szerves anyag mineralizációjához és az ásványosodás során képződött $\mathrm{NH}_{4}$ nitrifikációjához.

A ${ }^{15} \mathrm{~N}$ szerves anyag $+\mathrm{NH}_{4} \mathrm{NO}_{3}$-kezelésben a két talajon eltérő mennyiségű ásványi$\mathrm{N}$-t határoztunk meg. A szoloncsák talajhoz adott N-mennyiségnek csak egy része volt kimutatható ásványi-N formában. Az adott körülmények elősegíthették a gázalakú $\mathrm{NH}_{3}$ veszteséget. Az érlelés kezdetén mindkét talajon a szerves anyag mineralizációja során a mikroorganizmusok a testük felépítéséhez a talajba adott $\mathrm{NO}_{3}-\mathrm{N}-\mathrm{t}$ használták fel. 35 napig az ásványosodás során nőtt az $\mathrm{NH}_{4}-\mathrm{N}$ mennyisége, a $\mathrm{NO}_{3}-\mathrm{N}$ csökkent, majd azt követően a nitrifikációs folyamatok felerösödésével az $\mathrm{NH}_{4}-\mathrm{N}$-tartalom csökkenésével arányosan, talajtól függően eltérő mértékben növekedett a $\mathrm{NO}_{3}-\mathrm{N}$ mennyisége.

A ${ }^{15} \mathrm{~N}$ szerves anyag $+\mathrm{NH}_{4} \mathrm{NO}_{3}$-kezelésben jól érzékelhető a talajok ásványi-N mennyiségének összefüggése a nitrogén mobilizációs-immobilizációs folyamataival, a talajban végbemenő változásaival ( $\mathrm{NH}_{4}-\mathrm{N}$ lekötődés, $\mathrm{NH}_{3}$-veszteség stb.).

A ${ }^{15} \mathrm{NH}_{4}{ }^{15} \mathrm{NO}_{3}$ és a ${ }^{15} \mathrm{~N}$-jelzett babszár jelentős mértékben növelték a talajok ásványi-N-tartalmát. A mintavételek átlagában a talajok összes ásványi-N mennyiségének 70-69 \%-a (207-239 mg N) a jelzett ammónium-nitrátból, míg közel a fele (48-44 \%-a, 56-64 mg N) a ${ }^{15} \mathrm{~N}$-jelzett szerves anyagból származott (3. táblázat). 
A ${ }^{15} \mathrm{~N}$-jelzett anyagból származó N-mennyiség (LATKOVICSNÉ, 1981)

\begin{tabular}{|c|c|c|c|c|c|c|c|c|}
\hline \multirow{2}{*}{ Kezelés } & \multicolumn{6}{|c|}{ A mintavétel ideje, nap } & \multirow{2}{*}{ Átlag } & \multirow{2}{*}{$\mathbf{S z D}_{5 \%}$} \\
\hline & 5. & 12. & 20. & 35. & 68. & 88. & & \\
\hline \multicolumn{9}{|l|}{ Szoloncsák talaj } \\
\hline \multicolumn{8}{|c|}{$N, \mathrm{mg} / \mathrm{kg}$ talaj } & \multirow{6}{*}{10} \\
\hline${ }^{15} \mathrm{NH}_{4}{ }^{15} \mathrm{NO}_{3}$ & 219 & 214 & 224 & 206 & 196 & 184 & 207 & \\
\hline${ }^{15} \mathrm{~N}$ szerves anyag & 46 & 51 & 69 & 52 & 60 & 55 & 56 & \\
\hline${ }^{15} \mathrm{~N}$ szerves anyag $+\mathrm{NH}_{4} \mathrm{NO}_{3}$ & 81 & 74 & 79 & 66 & 76 & 60 & 73 & \\
\hline Átlag & 115 & 113 & 124 & 108 & 111 & 100 & 112 & \\
\hline $\mathrm{SzD}_{5 \%}$ & & & 7 & & & & 17 & \\
\hline \multicolumn{9}{|c|}{ Az összes ásványi-N \%-ában } \\
\hline${ }^{15} \mathrm{NH}_{4}{ }^{15} \mathrm{NO}_{3}$ & 71 & 71 & 75 & 68 & 68 & 68 & 70 & \multirow{5}{*}{3} \\
\hline${ }^{15} \mathrm{~N}$ szerves anyag & 51 & 46 & 55 & 38 & 50 & 50 & 48 & \\
\hline${ }^{15} \mathrm{~N}$ szerves anyag $+\mathrm{NH}_{4} \mathrm{NO}_{3}$ & 29 & 28 & 33 & 25 & 32 & 26 & 29 & \\
\hline Átlag & 50 & 49 & 54 & 44 & 50 & 48 & 49 & \\
\hline $\mathrm{SzD}_{5 \%}$ & & & 3 & & & & 6 & \\
\hline \multicolumn{9}{|c|}{ Az adott nitrogén \%-ában } \\
\hline${ }^{15} \mathrm{NH}_{4}{ }^{15} \mathrm{NO}_{3}$ & 70 & 69 & 72 & 66 & 63 & 59 & 66 & \multirow{5}{*}{7} \\
\hline${ }^{15} \mathrm{~N}$ szerves anyag & 37 & 41 & 56 & 42 & 49 & 45 & 45 & \\
\hline${ }^{15} \mathrm{~N}$ szerves anyag $+\mathrm{NH}_{4} \mathrm{NO}_{3}$ & 66 & 60 & 65 & 54 & 62 & 49 & 59 & \\
\hline Átlag & 57 & 56 & 64 & 54 & 58 & 51 & 56 & \\
\hline $\mathrm{SzD}_{5 \%}$ & & & 5 & & & & & \\
\hline \multicolumn{9}{|c|}{ Gyengén szologyosodott sztyeppesedő réti szolonyec talaj } \\
\hline & & $N$, & $/ \mathrm{kg} \mathrm{to}$ & & & & & \\
\hline${ }^{15} \mathrm{NH}_{4}{ }^{15} \mathrm{NO}_{3}$ & 256 & 237 & 247 & 227 & 241 & 228 & 239 & \multirow{5}{*}{13} \\
\hline${ }^{15} \mathrm{~N}$ szerves anyag & 68 & 50 & 62 & 45 & 72 & 86 & 64 & \\
\hline${ }^{15} \mathrm{~N}$ szerves anyag $+\mathrm{NH}_{4} \mathrm{NO}_{3}$ & 156 & 82 & 101 & 79 & 88 & 86 & 99 & \\
\hline Átlag & 160 & 123 & 137 & 117 & 134 & 133 & 134 & \\
\hline $\mathrm{SzD}_{5 \%}$ & & & 10 & & & & 23 & \\
\hline \multicolumn{9}{|c|}{ Az összes ásványi-N\%-ában } \\
\hline${ }^{15} \mathrm{NH}_{4}{ }^{15} \mathrm{NO}_{3}$ & 81 & 72 & 73 & 64 & 63 & 64 & 69 & \multirow{5}{*}{4} \\
\hline${ }^{15} \mathrm{~N}$ szerves anyag & 59 & 40 & 45 & 31 & 43 & 48 & 44 & \\
\hline${ }^{15} \mathrm{~N}$ szerves anyag $+\mathrm{NH}_{4} \mathrm{NO}_{3}$ & 38 & 27 & 31 & 23 & 26 & 29 & 29 & \\
\hline Átlag & 60 & 46 & 50 & 39 & 44 & 47 & 47 & \\
\hline $\mathrm{SzD}_{5 \%}$ & & & 5 & & & & 9 & \\
\hline \multicolumn{9}{|c|}{ Az adott nitrogén \%-ában } \\
\hline${ }^{15} \mathrm{NH}_{4}{ }^{15} \mathrm{NO}_{3}$ & 82 & 76 & 79 & 73 & 77 & 73 & 77 & \multirow{5}{*}{10} \\
\hline${ }^{15} \mathrm{~N}$ szerves anyag & 50 & 37 & 45 & 33 & 53 & 63 & 47 & \\
\hline${ }^{15} \mathrm{~N}$ szerves anyag $+\mathrm{NH}_{4} \mathrm{NO}_{3}$ & 115 & 60 & 74 & 53 & 65 & 63 & 73 & \\
\hline Átlag & 82 & 58 & 66 & 54 & 65 & 67 & 65 & \\
\hline $\mathrm{SzD}_{5 \%}$ & & & 7 & & & & & \\
\hline
\end{tabular}

A ${ }^{15} \mathrm{~N}$ szerves anyag $+\mathrm{NH}_{4} \mathrm{NO}_{3}$ kezelésben az ásványi-N formában meghatározott $\mathrm{N}$-nek, a mintavételek átlagában, $29 \%$-a (73-99 mg N) származott a ${ }^{15} \mathrm{~N}$-jelzett szerves anyagból; valamennyi esetben felülmúlta a ${ }^{15} \mathrm{~N}$ szerves anyag kezelésben kapott értékeket. Ezek az adatok igazolják, hogy szikeseken is (más talajokhoz hasonlóan) a szerves anyaggal együtt adott N-mütrágya kedvezően befolyásolja a szerves anyag lebontását. 
A közel 3 hónapos érlelés után - a mintavételek átlagában - az ${ }^{15} \mathrm{NH}_{4}{ }^{15} \mathrm{NO}_{3} 66$ $77 \%$-a, ${ }^{15} \mathrm{~N}$-jelzett szerves anyag kezelésben 45-47, ill. 59-73\%-a maradt ásványi-N formában. A kedvezőbb tulajdonságú gyengén szologyosodott sztyeppesedő réti szolonyec talajba adott $\mathrm{N}$-jének nagyobb részaránya maradt ásványi- $\mathrm{N}$ formában.

A kísérlet befejezésekor a talajban meghatározott kötött $\mathrm{NH}_{4}-\mathrm{N}$ mennyisége és összes-N-tartalma alapján számszerüen becsülhető az ${ }^{15} \mathrm{NH}_{4}{ }^{15} \mathrm{NO}_{3}$ és a ${ }^{15} \mathrm{~N}$-jelzett szerves anyag $\mathrm{N}$-jének az érlelés során megkötődött $\mathrm{N}$-mennyisége ill. $\mathrm{N}$-vesztesége. A két szikes talaj összes- $\mathrm{N}$ és kötött $\mathrm{NH}_{4}-\mathrm{N}$ mennyisége jelentősen eltér (4. táblázat), eltérö termékenységükkel összefüggően. A kezelések hatása kimutatható a talajok kötött $\mathrm{NH}_{4}$ $\mathrm{N}$ mennyiségének változásában.

4. táblázat

A ${ }^{15} \mathrm{~N}$-jelzett anyagból származó kötött $\mathrm{NH}_{4}-\mathrm{N}$ és az összes-N mennyisége

(LATKOVICSNÉ, 1981)

\begin{tabular}{|c|c|c|c|c|c|c|c|c|}
\hline \multirow{3}{*}{ Kezelés } & \multicolumn{4}{|c|}{ Kötött $\mathrm{NH}_{4}-\mathrm{N}$} & \multicolumn{4}{|c|}{ Összes-N } \\
\hline & \multirow{2}{*}{$\begin{array}{c}\mathrm{mg} / \mathrm{kg} \\
\text { talaj }\end{array}$} & \multicolumn{2}{|c|}{ jelzett anyagból } & \multirow{2}{*}{$\begin{array}{l}\text { adott N } \\
\text { \%-ában }\end{array}$} & \multirow{2}{*}{$\begin{array}{c}\mathrm{mg} / \mathrm{kg} \\
\text { talaj }\end{array}$} & \multicolumn{2}{|c|}{ jelzett anyagból } & \multirow{2}{*}{$\begin{array}{l}\text { adott N } \\
\text { \%-ában } \\
\end{array}$} \\
\hline & & $\%$ & mg & & & $\%$ & mg & \\
\hline \multicolumn{9}{|c|}{ Szoloncsák talaj } \\
\hline Kontroll & 103 & - & - & - & 644 & - & - & - \\
\hline${ }^{15} \mathrm{NH}_{4}{ }^{15} \mathrm{NO}_{3}$ & 113 & 9,4 & 10,7 & 3,4 & 864 & 27,1 & 234,5 & 75,6 \\
\hline${ }^{15} \mathrm{~N}$ szerves anyag & 115 & 6,4 & 7,3 & 5,9 & 771 & 15,5 & 127,2 & 103,9 \\
\hline $\begin{array}{c}{ }^{15} \mathrm{~N} \text { szerves anyag } \\
+\mathrm{NH}_{4} \mathrm{NO}_{3}\end{array}$ & 119 & 1,0 & 1,1 & 0,9 & 881 & 8,6 & 75,8 & 61,9 \\
\hline $\mathrm{SzD}_{5 \%}$ & & & 1,2 & & & & 42,0 & \\
\hline \multicolumn{9}{|c|}{ Gyengén szologyosodott sztyeppesedö réti szolonyec } \\
\hline Kontroll & 248 & - & - & - & 2524 & - & - & - \\
\hline${ }^{15} \mathrm{NH}_{4}{ }^{15} \mathrm{NO}_{3}$ & 273 & 6,2 & 17,0 & 5,4 & 2864 & 9,6 & 275,7 & 88,9 \\
\hline${ }^{15} \mathrm{~N}$ szerves anyag & 269 & 1,9 & 5,0 & 3,6 & 2715 & 4,7 & 126,4 & 92,9 \\
\hline $\begin{array}{l}{ }^{15} \mathrm{~N} \text { szerves anyag } \\
+\mathrm{NH}_{4} \mathrm{NO}_{3}\end{array}$ & 277 & 0,9 & 2,5 & 1,8 & 2924 & 3,9 & 114,4 & 84,1 \\
\hline $\mathrm{SzD}_{5 \%}$ & & & 3,6 & & & & 20,6 & \\
\hline
\end{tabular}

A legnagyobb mértékü növekedést a ${ }^{15} \mathrm{~N}$ szerves anyag $+\mathrm{NH}_{4} \mathrm{NO}_{3}$-kezelésben kaptuk, amikor is mindkét talajon a kontrollhoz viszonyított kötött $\mathrm{NH}_{4}-\mathrm{N}$ mennyiség több mint $11 \%$-kal nőtt, elsősorban az ammónium-nitrát N-je kötődött meg. Az izotóp-indikáció alapján számított értékek szerint - kezelésektől függően - az adott ${ }^{15} \mathrm{~N}$ mennyiségek 3,4-5,9 \%-a kötődött meg. A ${ }^{15} \mathrm{~N}$ szerves anyag $+\mathrm{NH}_{4} \mathrm{NO}_{3}$-kezelés adatai világosan mutatják, hogy a N-mütrágyázás csökkenti a szerves anyagból származó N megkötődését.

A kezelések hatása a talajok összes-N-tartalmára jól megfigyelhető. Mindkét talajon $\mathrm{N}$-veszteség mutatható ki. A legnagyobb $\mathrm{N}$-veszteséget a ${ }^{15} \mathrm{NH}_{4}{ }^{15} \mathrm{NO}_{3}$-kezelésben mértük. A ${ }^{15} \mathrm{~N}$-jelzett szerves anyag nitrogénjének vesztesége lényegében elhanyagolható, az ammónium-nitrát hatására növekedett, amely összefügg a mikrobiológiai folyamatok aktivitásával, az élénkebb mineralizációval.

Szoloncsák talajon a N-vegyületekből származó N-veszteség felülmúlja a gyengén szologyosodott sztyeppesedő réti szolonyecen kapott értékeket. Ezek az eredmények is igazolják a szoloncsák talajok N-tápanyag-gazdálkodásával kapcsolatos korábbi megállapításokat. 


\section{Tenyészedény-kísérletek}

Az érleléses modellkísérletek eredményei rámutattak, hogy a szikesek eltérő jellegzetes tulajdonságai nagymértékben befolyásolták a talajban lévő, ill. az adott N-vegyületek átalakulását, a N-tápelem felvehetőségét, a N-veszteséget stb.

A növények N-ellátásának fontos szerepe van a szikes talajokon folytatott növénytermesztésben, emellett kedvezően hat a szikes talajokban lejátszódó biológiai folyamatokra, a mikroszervezetek életmüködéséhez szükséges nitrogént szolgáltatva.

Ismerve a szikes talajok N-ellátottságával összefüggő kedvezőtlen tulajdonságait, fontosnak tartottuk tanulmányozni a fiatal csíranövények $\mathrm{N}$-felvételét. A tenyészedénykísérletek adatai ${ }^{15} \mathrm{~N}$-jelzett vegyületekből felvett $\mathrm{N}$-mennyiségekről, háromhetes őszi búza, ill. négyhetes kukoricanövények trágya-N felvételéröl és a N-mütrágyák hasznosulásáról adnak értékes információt.

A kísérlethez karbonátos szoloncsákos szolonyec talajt $(\mathrm{B})\left(\mathrm{pH}=8,0, \mathrm{CaCO}_{3}\right.$-tartalom $12 \%$, humusz $2,8 \%$ ), ill. szologyosodott szolonyec talajt (A) ( $\mathrm{pH}=5,6$, humusz $=4 \%$ ) használtunk. N-forrásként ${ }^{15} \mathrm{~N}$-jelzett $\mathrm{Ca}\left({ }^{15} \mathrm{NO}_{3}\right)_{2},{ }^{15} \mathrm{NH}_{4}{ }^{15} \mathrm{NO}_{3}$ és pétisót adtunk a talajhoz.

A két jellegzetes szikes talajon a fiatal búzanövények tápelemfelvételében jelentős különbség alakult ki. A növények által kivont N-, $\mathrm{P}_{2} \mathrm{O}_{5^{-}}, \mathrm{K}_{2} \mathrm{O}-$, ill. CaO-mennyiség a szologyos szolonyec talajon jóval meghaladta a szoloncsákos szolonyec talajon kapott értékeket. A talajban lévő oldható sók mennyisége és összetétele nagymértékben gátolták a növény fejlődését és tápelemfelvételét.

A termékenyebb, kedvezőbb tulajdonságokkal rendelkező szologyos szolonyec talajon a ${ }^{15} \mathrm{~N}$-jelzett trágyákból (kalcium-nitrát, pétisó, ill. ammónium-nitrát) a N-vegyületek hatóanyaga 6,6, 16,5, ill. 14,1 \%-ban hasznosult. N-forrástól függően 4,4, 10,9, ill. $9,3 \mathrm{mg} \mathrm{N}$-t vettek fel a növények. A szoloncsákos szolonyec talajon a fiatal növények az adott ${ }^{15} \mathrm{~N}$-mütrágyák $\mathrm{N}$-jének csak 1,3, 2,9, ill. 2,6 \%-át értékesítették és a kivont trágya-N mindössze $0,9,1,9$, ill. 1,7 mg volt. Ezek az eredmények meggyőzően igazolják, hogy a fiatal búzanövénykék - a mag tartaléktápanyagainak felhasználásával egy időben - a talajban rendelkezésre álló N-tápelemet is hasznosítják. A kalcium-nitrát Njének hasznosulása mintegy fele az ammónium-nitrát kezelésben kapott értékeknek. Az adott viszonyok között feltehetően a növény fejlettsége, az asszimilációs folyamatok aktivitása nem állt összhangban a növény rendelkezésére álló $\mathrm{NO}_{3}$-mennyiséggel. Ezek az eredmények arra utalnak, hogy kedvezőtlen tulajdonságú talajokon, elsősorban a növények fejlődésének kezdetén a N-ellátás biztosítása érdekében elönyösebb a $\mathrm{NO}_{3}$ - és az $\mathrm{NH}_{4}-\mathrm{N}$ együttes alkalmazása.

A kukoricanövénnyel végzett kísérletekben a két szikes talajon a N-hatás szintén talajtípustól és N-forrástól függően változott. A négyhetes kukoricanövény N-felvétele 27,1-48,6 mg N között változott (5. táblázat). Mindkét talajon a ${ }^{15} \mathrm{~N}$-jelzett ammóniumszulfát esetében kaptuk a legkisebb $\mathrm{N}$-hozamot és a ${ }^{15} \mathrm{~N}$-vegyületből származó $\mathrm{N}$ mennyiséget is $(4,1$ ill. $6,8 \mathrm{mg} \mathrm{N})$. A többi N-forrás esetében a fiatal kukoricanövénykék 10,1-16,3 mg trágya-N-t vettek fel.

Az izotóphígítás módszerével számított N-hasznosulási értékek a kezelések többségénél hasonló tendenciát mutattak. $\mathrm{A}^{15}\left(\mathrm{NH}_{4}\right) \mathrm{SO}_{4}$ nitrogénje hasznosult a legkisebb mértékben (10,2-17,0\%-ban), a többi $\mathrm{N}$-forrás $\mathrm{N}$-jét a növények szignifikánsan jobban értékesítették (25,2-42,0\%). Ezek a viszonylag magas N-hasznosulási értékek arra hív- 
5. táblázat

A kukorica $\mathrm{N}$-felvétele és a $\mathrm{N}$-vegyületek hatóanyagának hasznosulása szologyos szolonyec (A) és szoloncsákos szolonyec (B) talajjal beállított tenyészedény-kísérletben (LATKOVICSNÉ, 1974a,b)

\begin{tabular}{|c|c|c|c|c|c|c|}
\hline \multirow{2}{*}{ Kezelés } & \multicolumn{2}{|c|}{ Felvett N, mg/edény } & \multicolumn{2}{|c|}{ Trágyából felvett, N/edény } & \multicolumn{2}{|c|}{ N-hasznosulás, \% } \\
\hline & $\mathbf{A}$ & B & A & B & $\mathbf{A}$ & B \\
\hline Kontroll & 27,1 & 35,1 & - & - & - & - \\
\hline${ }^{15} \mathrm{NH}_{4}{ }^{15} \mathrm{NO}_{3}$ & 39,7 & 48,6 & 13,9 & 12,7 & 34,7 & 31,7 \\
\hline${ }^{15} \mathrm{NH}_{4} \mathrm{Cl}$ & 38,8 & 42,2 & 16,8 & 10,1 & 42,0 & 25,2 \\
\hline $\mathrm{Na}^{15} \mathrm{NO}_{3}$ & 37,8 & 45,9 & 11,2 & 11,7 & 28,0 & 29,2 \\
\hline $\mathrm{K}^{15} \mathrm{NO}_{3}$ & 41,8 & 44,5 & 15,5 & 11,7 & 38,7 & 29,2 \\
\hline$\left({ }^{15} \mathrm{NH}_{4}\right)_{2} \mathrm{SO}_{4}$ & 33,2 & 35,6 & 6,8 & 4,1 & 17,0 & 10,2 \\
\hline${ }^{15} \mathrm{NH}_{4} \mathrm{OH}$ & 41,1 & 46,6 & 13,6 & 15,8 & 34,0 & 39,5 \\
\hline $\mathrm{SzD}_{5 \%}$ & \multicolumn{2}{|c|}{6,3} & \multicolumn{2}{|c|}{3,7} & \multicolumn{2}{|c|}{9,1} \\
\hline
\end{tabular}

ják fel a figyelmet, hogy szikes talajokon is fontos szerepe van a fiatal kukoricanövény fejlődése szempontjából a növény N-ellátásnak.

A háromhetes kukoricanövény $\mathrm{NH}_{4}-\mathrm{N}$ - és $\mathrm{NO}_{3}$-N-felvételének tanulmányozására végzett kísérletből (LATKOVICSNÉ \& VARGA, 1971) - a két szikes talajra vonatkozó adatok szerint - a növények N-kivonása ${ }^{15} \mathrm{~N}$-jelzett ammónium-nitrátból azonos volt: 14,5 $\mathrm{NH}_{4}-\mathrm{N}$ és 14,4 $\mathrm{NO}_{3}-\mathrm{N}$ a szoloncsákos szolonyec, ill. 15,8 $\mathrm{NH}_{4}-\mathrm{N}$ és $16,0 \mathrm{NO}_{3}-\mathrm{N}$ a szolonyec talaj esetében. A két szikes talaj között sem mutatkozott szignifikáns eltérés. Ugyanakkor az ammónium-nitrát ${ }^{15} \mathrm{NH}_{4}$-N-jéböl mindkét talajon többet vettek fel a növények, mint a ${ }^{15} \mathrm{NO}_{3}$-N-böl. A növények által kivont $\mathrm{N}$-nek talajtól függően 7,6 (szoloncsákos szolonyec) ill. 10,4 \%-a (szolonyec) származott az ${ }^{15} \mathrm{NH}_{4}-\mathrm{N}-b o ̋ l$, míg a ${ }^{15} \mathrm{NO}$-N-nek csak 4,8 ill. 6,8 \%-a.

A termékenyebb talajokon általában kedvezőbb a $\mathrm{NO}_{3}-\mathrm{N}$ felvétele, ill. közel azonos az $\mathrm{NH}_{4}-\mathrm{N}$ - és $\mathrm{NO}_{3}-\mathrm{N}$ hasznosulása.

Adataink a korábbi megállapításokat is igazolják miszerint a kedvezőtlen tulajdonsággal rendelkező talajokon a fiatal növények az ${ }^{15} \mathrm{NH}_{4}$ - $\mathrm{N}$-felvételét előnyben részesítik a ${ }^{15} \mathrm{NO}$-N-nel szemben.

A koncentrált $\mathrm{N}$-műtrágyák hatásának tanulmányozása során a karbamid hatását vizsgáltuk tenyészedény-kísérletben (LATKOVICSNÉ \& MÁTÉ, 1968). A karbamid-N hatására a fiatal kukoricanövénykék szárazanyaghozama mind a szoloncsákos szolonyec talajon $(0,68 \mathrm{~g} /$ edény), mind a szolonyec talajon $(1,08 \mathrm{~g} /$ edény) jelentősen nött. A növények által felvett összes-N mennyiség 37,5, ill. 45,6 \%-a (8,1 ill. 18,8 mg N) származott a ${ }^{15} \mathrm{~N}$-jelzett karbamidból, míg homokon több mint $80 \%$-a $(22,5 \mathrm{mg} \mathrm{N})$. A korábbi eredményekhez hasonlóan igazolt, hogy a négyhetes kukoricanövényék optimális viszonyok között szikes talajon is képesek az adott N-mennyiség jelentős részét $(20,2$, ill. 47,0 \%-át) hasznosítani. Az eltérő mértékủ hasznosulási értékek a két szikes talaj eltérő tulajdonságaival, a N-átalakulási folyamataival, ill. a növény $\mathrm{N}$-felvételére kifejtett hatásával magyarázható.

A talajbank talajaival beállított, több osztállyal közösen végzett tenyészedény-kísérletünkben hazánk reprezentatív talajtípusát képviselő talajok tápelem-ellátottsága és a talajtulajdonságok közötti összefüggésekre kívántunk információkat szerezni. 
A közös, angolperjével beállított tenyészedény-kísérletünk 1 . kezelésében csak ${ }^{15} \mathrm{~N}$ jelzett ${ }^{15} \mathrm{NH}_{4}{ }^{15} \mathrm{NO}_{3}$-ot adtunk, amely lehetőséget adott az ammónium-nitrát átalakulási folyamatainak nyomon követésére a talajban és a növények által történő hasznosulásának jellemzésére a talajok természetesen tápelem-ellátottsága mellett. A ${ }^{15} \mathrm{~N}$-jelzett mütrágyát vetéskor ( $50 \mathrm{mg} \mathrm{N} /$ edény), a továbbiakban azonos adagban pedig hetente fejtrágyának oldatként adtuk. Az 5. vágásig összesen 738,33 $\mathrm{mg}{ }^{15} \mathrm{~N} /$ edény hatóanyagnak megfelelö ${ }^{15} \mathrm{~N}$-jelzett ${ }^{15} \mathrm{NH}_{4}{ }^{15} \mathrm{NO}_{3}$-ot alkalmaztunk. A tenyészidő alatt az angolperjét 21-23 naponként, összesen hatszor vágtuk. Öt vágás esetén a halmozott N-hatást mértük, míg a 6. vágásnál a korábban adott ${ }^{15} \mathrm{~N}$-vegyület utóhatását mértük.

A kísérletsorozatból a (1) mélyben szolonyeces csernozjom, Orosháza $(\mathrm{pH}(\mathrm{KCl})$ 7,1; $\mathrm{CaCO}_{3} 1,8 \%$; $\mathrm{H} 3,4 \%$ ); (2) réti szolonyec, Hajdúböszörmény $(\mathrm{pH}(\mathrm{KCl})$ 5,8; $\mathrm{H} \mathrm{6,4}$ $\%$ ) és (3) sztyeppesedő réti szolonyec, Karcag $(\mathrm{pH}(\mathrm{KCl})$ 4,8; H 3,9 \%) talajjal végzett kísérletek eredményeit mutatom be. Az angolperje legnagyobb szárazanyaghozamát az első vágáskor kaptuk. A vágások számának növekedésével a szárazanyag-mennnyiség folyamatosan csökkent. A legkisebb mennyiséget az 5. vágáskor mértük. Az utolsó, 6. vágású növények szárazanyaghozama viszont növekedett, ami azzal magyarázható, hogy az előzőkhöz viszonyítva két nappal később, a 23. napon került levágásra.

A legnagyobb szárazanyaghozamot és a növények által kivont N-mennyiségt (6. táblázat) a sztyeppesedő réti szolonyec talajon (3) értük el, azt követte a réti szolonyec (2), majd végül a mélyben szolonyeces csernozjom (1). Ezek átlagadatok, csak bizonyos mértékig fejezik ki a talajtípusok termékenységét, természetes tápanyagszolgáltató képességét azonos N-ellátási szinten. Az egyes talajtípusokon belül megfigyelhető különbségek feltételezhetően szoros összefüggésben vannak a talajtípusokat jellemző jellegzetes talajtulajdonságok eltérő mértékével. A ${ }^{15} \mathrm{~N}$-jelzett $\mathrm{N}$-trágyából származó $\mathrm{N}$ mennyiségek az összes felvett $\mathrm{N} \%$-ában vágásonként változtak. Az első vágás idején ez az érték 63-64\%, vagyis a három szikes talajon közel azonos értéket kaptunk. A vágások számának növekedésével a $\mathrm{N}$-trágyából származó $\mathrm{N}$ részaránya a folyamatos ${ }^{15} \mathrm{~N}$-ellátás hatására nőtt, az ötödik vágás idejére elérte a 93-97\%-ot. A hatodik vágáskor a

$$
\text { 6. táblázat }
$$

Az angolperje szárazanyaghozama és a felvett $\mathbf{N}$ mennyisége mélyben szolonyeces csernozjom (1), réti szolonyec (2) és sztyeppesedő réti szolonyec (3) talajjal beállított tenyészedény-kísérletben

\begin{tabular}{|c|c|c|c|c|c|c|}
\hline \multirow{2}{*}{$\begin{array}{c}\text { Talaj } \\
\text { jelzése }\end{array}$} & \multicolumn{2}{|c|}{ Szárazanyaghozam, g/edény } & \multicolumn{3}{c|}{ Kivont N-mennyiség, mg N/edény } \\
\cline { 2 - 7 } & Föld feletti & Gyökér & Összesen & Föld feletti & Gyökér & Összes \\
\hline 1. & 6,6 & 1,3 & 7,9 & 247 & 22 & 269 \\
2. & 7,3 & 1,0 & 8,3 & 295 & 15 & 310 \\
3. & 8,8 & 1,5 & 10,3 & 321 & 20 & 341 \\
\hline
\end{tabular}

\begin{tabular}{|c|c|c|c|c|c|c|}
\hline \multirow{3}{*}{$\begin{array}{c}\text { Talaj } \\
\text { jelzése }\end{array}$} & \multicolumn{5}{|c|}{${ }^{15} \mathrm{~N}$ trágyából származó $\mathrm{N}$-mennyiség } & \multirow{3}{*}{$\begin{array}{c}\text { Haszno- } \\
\text { sulás } \\
\% \\
\end{array}$} \\
\hline & \multicolumn{2}{|c|}{ \%-ban } & \multicolumn{3}{|c|}{ mg ${ }^{15}$ N/edény } & \\
\hline & Föld feletti & Gyökér & Föld feletti & Gyökér & Összes & \\
\hline 1. & 82 & 64 & 197 & 14 & 211 & 29 \\
\hline 2. & 84 & 71 & 240 & 11 & 251 & 34 \\
\hline 3. & 84 & 64 & 260 & 13 & 273 & 37 \\
\hline
\end{tabular}


trágyából származó részarány természetesen csökkent, mivel csak N-utóhatást mértünk. A hat vágás átlagában jelentős eltérés a három talajon nem mutatkozott, a különböző szolonyec talajokon az angolperje összes N-hozamának jelentős része (82-84 \%-a) származott ${ }^{15} \mathrm{~N}$-jelzett ammónium-nitrátból.

A ${ }^{15} \mathrm{~N}$-jelzett trágyából a növények első vágáskor, a talajtól függően $40-57 \mathrm{mg} \mathrm{N}$-t vettek fel. A 3. vágásig nőtt, ill. nem változott, majd azt követően csökkent a felvett trágya-N mennyisége. Az utolsó (6.) vágás idején a ${ }^{15} \mathrm{~N}$-jelzett trágyából származó $\mathrm{N}$ mennyiség 25-28 mg N/edény volt. Feltételezhetö, hogy a folyamatos N-ellátás mellett a nitrogén beépüléséhez szükséges optimális feltételek közül többek között a harmonikus tápelemellátás ( $\mathrm{K}$ és $\mathrm{P}$ stb.) gátló tényezőként hathatott.

A három szikes talajon a növények a tenyészidő alatt összesen 197-260 mg N-t vettek fel a trágyából. A gyökerekben lévő trágya-N közel azonos értéket mutat (11-14 mg $\mathrm{N} /$ edény). A növény föld feletti részében és a gyökérben kimutatott ${ }^{15} \mathrm{~N}$-mennyiség 211-273 mg/edény. Amennyiben a kapott értéket a tenyészidő alatt adott összes ${ }^{15} \mathrm{~N}$ mennyiséghez viszonyítjuk, 29, 34 ill. $37 \%$ hasznosulási értéket kapunk. A ${ }^{15} \mathrm{~N}$-jelzett trágyának a vártnál alacsonyabb hasznosulási értékei arra utalnak, hogy az adott tenyészedény-kísérletben az optimális vízellátás mellett a szikes talajok kedvezőtlen tulajdonságai, ill. az egyes tápelemek hiánya korlátozhatta a K-tápelem hasznosulását. Ezek az eredmények a harmonikus tápelem-ellátottság jelentőségére hívják fel a figyelmet.

A talajok N-ellátottságára utaló adatok (7. táblázat) alapján a mélyben szolonyeces csernozjom és a sztyeppesedő réti szolonyec talaj összes-N-tartalma a humuszmennyiségnek megfelelően közel azonos (2305 ill. $2366 \mathrm{mg} \mathrm{N} / \mathrm{kg}$ talaj), viszont a 6,4 \% humusztartalmú réti szolonyec összes-N-tartalma $3528 \mathrm{mg} \mathrm{N} / \mathrm{kg}$ talaj. A légszáraz talajminták ásványi $\mathrm{NH}_{4}-\mathrm{N}$ és $\mathrm{NO}_{3}-\mathrm{N}$ mennyisége $14-24,1 \mathrm{mg} \mathrm{N} / \mathrm{kg}$ talaj, az összes- $\mathrm{N}$ mennyiség $0,6-1 \%$-a.

A talajok kötött $\mathrm{NH}_{4}-\mathrm{N}$ menyisége összefüggést mutat a leiszapolható részek \%-os arányával, az ammóniumion megkötése azokon a talajokon jelentős, amelyeknél a leiszapolható részek aránya a legnagyobb (pl. sztyeppesedő réti szolonyec 295,9 mg $\mathrm{NH}_{4}$ $\mathrm{N})$. Természetesen az agyagfrakciók mennyiségén túlmenően azok minősége, összetétele és az egyéb talajtulajdonságok is jelentősen befolyásolják az $\mathrm{NH}_{4}$-ion megkötését. A három vizsgált szikes talaj kötött $\mathrm{NH}_{4}-\mathrm{N}$ mennyisége a talajok összes $\mathrm{N}$-mennyiségének 5,8-12,5\%-a.

7. táblázat

A mélyben szolonyeces csernozjom (1), réti szolonyec (2) és sztyeppesedő réti szolonyec (3) talajok N-ellátottsága tenyészedény-kísérletben

\begin{tabular}{|c|c|c|c|c|c|c|c|}
\hline \multirow[b]{2}{*}{ Talaj } & \multirow{2}{*}{ Összes $\mathbf{N}$} & \multirow{2}{*}{$\mathbf{N H}_{4}-\mathbf{N}$} & \multirow{2}{*}{$\mathrm{NO}_{3}-\mathrm{N}$} & \multirow{2}{*}{$\begin{array}{c}\mathrm{NH}_{4}-\mathrm{N}+ \\
\mathrm{NO}_{3}-\mathrm{N} \\
\end{array}$} & \multirow{2}{*}{$\begin{array}{c}\text { Ásványi-N } \\
\text { az összes } \\
\text { N \%-ában }\end{array}$} & \multicolumn{2}{|c|}{ Kötött $\mathrm{NH}_{4}-\mathrm{N}$} \\
\hline & & & & & & $\begin{array}{c}\mathrm{mg} \mathrm{N} / \mathrm{kg} \\
\text { talaj }\end{array}$ & $\begin{array}{c}\text { az összes- } \\
\text { \%-ában }\end{array}$ \\
\hline \multicolumn{8}{|c|}{ A kisérlet beállitásakor } \\
\hline 1 & 2305 & 7,7 & 6,3 & 14,0 & 0,6 & 167,3 & 7,3 \\
\hline 2 & 3528 & 9,0 & 12,0 & 21,0 & 0,6 & 203,3 & 5,8 \\
\hline 3 & 2366 & 9,7 & 14,4 & 24,1 & 1,0 & 295,9 & 12,5 \\
\hline \multicolumn{8}{|c|}{ A kisérlet befejezése után (1978. jún. 15-nov. 1., 138 nap, 6. vágás) } \\
\hline 1 & 3086 & 5,6 & 478,6 & 484,2 & 15,7 & 179 & 5,8 \\
\hline 2 & 3657 & 51,8 & 357,1 & 408,9 & 11,2 & 243 & 6,6 \\
\hline 3 & 2266 & 104,7 & 221,4 & 326,1 & 14,4 & 356 & 15,7 \\
\hline
\end{tabular}


A kísérlet befejezése utáni talajvizsgálatok igazolják, hogy eltérő a talajban maradt trágya-N mennyisége és szoros összefüggést mutat a növények N-felvételével (7. táblázat). A folyamatosan adott $\mathrm{N}$-tápelem hatására jelentősen nőtt a talajok ásványi-Ntartalma. Míg a 7,4 pH(KCl)-értékü mélyben szolonyeces csernozjom talajon az ásványi $\mathrm{N}$-mennyiség jelentős részét a $\mathrm{NO}_{3}-\mathrm{N}$ adta $\left(478,6 \mathrm{mg} \mathrm{NO}_{3}-\mathrm{N} / \mathrm{kg}\right.$ talaj), a réti szolonyec talajon $\left(\mathrm{pH}(\mathrm{KCl})\right.$ 5,8) a $\mathrm{NO}_{3}-\mathrm{N}$ kisebb növekedésével egy időben nőtt az $\mathrm{NH}_{4}-\mathrm{N}$ mennyisége is. Ez a folyamat még kifejezettebb a sztyeppesedő réti szolonyec talajjal (pH(KCl) 4,8) beállított kísérletben, ahol a 221,4 $\mathrm{NO}_{3}-\mathrm{N}$-tartalom mellett a talaj $\mathrm{NH}_{4}-\mathrm{N}$ mennyisége elérte a 104,7 mg-ot. A N-trágyázás hatására a talajok ásványi-N-tartalma elérte az összes-N-tartalmuk 11,2-15,7 \%-át.

A talajok kötött $\mathrm{NH}_{4}-\mathrm{N}$ mennyisége a talajtípustól függően eltérő mértékben növekedett. Az összes $\mathrm{N}$ mennyiségéhez viszonyított értéke a mélyben szolonyeces csernozjom talajon csökkent, míg a két másik talajon a leiszapolható részek \%-os arányával és egyéb talajtulajdonságokkal összefüggően eltérő mértékben növekedett.

$\mathrm{A}^{15} \mathrm{NH}_{4}{ }^{15} \mathrm{NO}_{3}$ felhasználása lehetőséget adott olyan számítások elvégzésére is, amelyek alapján becsülhető a folyamatosan, hosszabb időn át adott N-mütrágya hasznosulása, N-hatóanyagának vesztesége stb. Az összesített adatok alapján megállapítható, hogy az adott viszonyok között az összes felhasznált mütrágya jelentős részét visszakaptuk. Az elözőekben már megállapítást nyert, hogy a növények által kivont Nmennyiség a talajba adott összes-N-mennyiség 29-37\%-a, a mélyben szolonyeces csernozjom, réti szolonyec és sztyeppesedő réti szolonyec talajok esetében 211, 251, ill. 273 mg N/edény. A talajban maradt trágya-N-mennyiség (504, 301 ill. $308 \mathrm{mg}$ ) az összes adott N-mennyiség 68, 41 ill. $42 \%$-a. Az edényenként összesen meghatározott trágya${ }^{15} \mathrm{~N} 715,552$ ill. $581 \mathrm{mg} \mathrm{N}$, a felhasznált összes N-mennyiség 97, 75 ill. $79 \%$-a.

Az adott viszonyok között, a több hónapig tartó kísérletben, a folyamatosan adagolt, végső soron nem kis mennyiségben kijuttatott N-ből a veszteség nem jelentős, talajtípustól függően 3-25\%. A legkisebb N-veszteséget a kedvezőbb tulajdonságot képviselö mélyben szolonyeces csernozjom talajon mértük, míg az alacsony pH-jú, rossz vízgazdálkodással rendelkező réti szolonyec, ill. sztyeppesedő réti szolonyec talajon a N-veszteség elérte a 21-25\%-ot. Ez a gázalakú N-veszteséggel, feltehetően a denitrifikációs folyamatok részére kialakult kedvező feltételekkel is magyarázható.

\section{Mikroparcellás kísérlet}

Szologyosodott réti szolonyec talajon ( $\mathrm{pH}(\mathrm{KCl}) 5,5$, humusz $4 \%$ ) (Palotás) beállított mikroparcellás gyepkísérletben a kora tavaszi $\mathrm{N}$-fejtrágyázás hatását vizsgáltuk ${ }^{15} \mathrm{~N}$ jelzett mütrágyák $\left({ }^{15} \mathrm{NH}_{4}{ }^{15} \mathrm{NO}_{3}, \mathrm{Ca}\left({ }^{15} \mathrm{NO}_{3}\right)_{2}\right.$ és $\left.\mathrm{CO}\left({ }^{15} \mathrm{NH}_{2}\right)_{2}\right)$ felhasználásával (LATKOVICS, 1974).

Első kaszáláskor a széna N-tartalmának 34, 39 ill. $32 \%$-a származott a fenti ${ }^{15} \mathrm{~N}$ mütrágyákból. Ez a részarány a 2. (14, 16 ill. $14 \%)$ ill. 3. (9, 12, $9 \%$ ) kaszálású széna $\mathrm{N}$-felvételében csökkent. A $100 \mathrm{~kg} \mathrm{~N} / \mathrm{ha}$ hatóanyagnak megfelelö N-mütrágyák - a három kaszálás együttes eredményei alapján közel azonos mértékben - 28, 27 ill. $31 \%$ ban hasznosultak: 17, 17, $19 \%$ az 1. kaszáláskor; $9,8,9 \%$ a 2. kaszáláskor; 2, 2, $3 \%$ a 3. kaszáláskor. 
Szabadföldi kisparcellás kisérlet

Az öntözés és a kalcium-nitrát növekvő N-adagjának hatását szologyosodott szolonyec talajon lévő ősgyepen beállított kísérletben vizsgáltuk (LATKOVICS, 1974). Az évente kiszórt 54, 103, ill. $162 \mathrm{~kg} \mathrm{~N} /$ ha hatóanyagnak megfelelö kalcium-nitrát minden évben jelentős szénaterméstöbbletet eredményezett öntözött és öntözetlen viszonyok között egyaránt.

Az öntözés hatása a kezelések átlagában kerül bemutatásra az 1. ábrán. A kezelésenként és évenként kapott eredmények az adott körülmények között az öntözés pozitív hatására utalnak. Az öntözés hatására részben az értékesebb elsőrendü füvek borítási

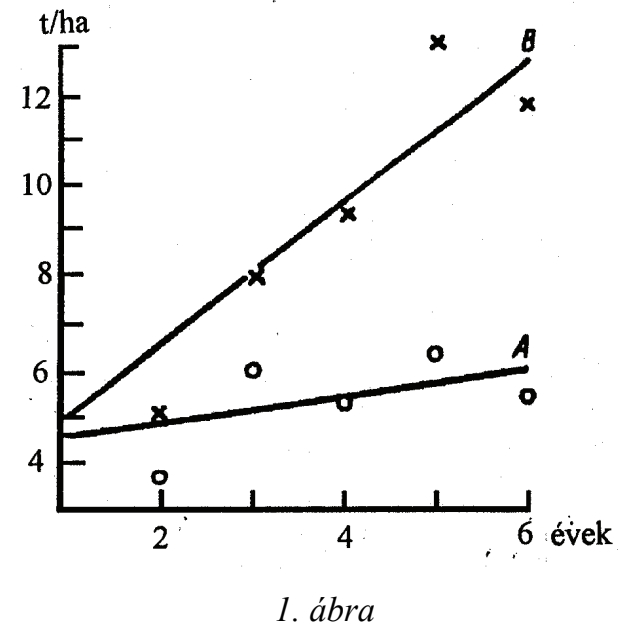

Az öntözés hatása az ősgyep szénatermésére, t/ha (86 \% sz.a.) (Szologyosodott szolonyec talaj, Palotás) (LATKOVICS, 1974) a) öntözés nélkül; b) öntözött

százalékának növekedésével (BODROGKÖZY, 1964) ill. pillangósok előtérbe kerülésével, részben a talaj természetes tápelemtartalékainak mobilizálásával, ill. a növényzet optimális vízellátásának biztosításával a környezetvédelmi szempontok figyelembevételével jelentősen növelhetö.

Az öntözés hatására jelentősen nőtt a széna tápelemhozama. A gyepnövényzet jobb Ca-ellátásában a kalcium-nitrát pozitív hatása mutatkozott meg. Az öntözés elsősorban a gyepnövényzet N- és Ca-hozamát növelte jelentösen, biztosítva a szénatermés kiváló minőségét.

Ugyancsak az ősgyepen beállított szabadföldi kísérletben öntözés mellett vizsgáltuk a növekvő adagban alkalmazott kalcium-nitrát és 150 q/ha mészkőpor hatását, ill. utóhatását (LATKOVICSNÉ et al., 1972). Az első évben a N- és P-mütrágyákat és a mészkőport ősszel szórtuk ki, kivéve az 5. kezelést, ahol a N-mütrágyát megosztva (fele összel, fele tavasszal) alkalmaztuk. A további években a mészkőpor utóhatását értékeltük. A Pés N-mütrágyákat évenként újból kiszórtuk, mégpedig a foszfort teljes egészében, a nitrogén felét ősszel, másik felét tavasszal. A tenyészidő folyamán évente két-három kaszálást végeztünk, a gyepnövényzet fejlödésétől függően.

A N-hatás a fünövényzet fejlődésében erősen megmutatkozott. A növényzet intenzív fejlődésével egy időben kedvezően változott a növénytársulás. A kalcium-nitrát, ill. ki- 
sebb mértékben a meszezés hatására növekedett az elsőrendü füvek (réti ecsetpázsit, réti perje, angol perje stb.) részaránya.

A kontroll- és a kisebb N-adagoknál (50-100 kg N/ha) az utolsó években az öntözés hatására a pillangósok erősen előtérbe kerültek. Az eredmények alapján (8. táblázat) a meszezés hatása $5 \%$-os szinten nem szignifikáns, bár a kezelések átlagában kapott mészhatás megközelíti a szignifikancia határát.

\section{8. táblázat}

A kalcium-nitrát hatása az ösgyep szénatermésére (t/ha) (86 \% szárazanyag, 6 év össz-termése) (szologyosodott szolonyec, Palotás)

(LATKOVICSNÉ et al., 1972)

\begin{tabular}{|c|c|c|c|c|c|c|}
\hline \multirow[b]{2}{*}{ Kezelés } & \multicolumn{2}{|c|}{$\mathbf{A}$} & \multicolumn{2}{|c|}{ B } & \multirow[b]{2}{*}{$\mathbf{B}-\mathbf{A}$} & \multirow[b]{2}{*}{$\mathrm{SzD}_{5 \%}$} \\
\hline & Mész nélkül & Többlet & $\begin{array}{c}150 \mathrm{q} / \mathrm{ha} \\
\text { mészkőpor }\end{array}$ & Többlet & & \\
\hline Kontroll & 34,0 & - & 37,6 & - & $+3,6$ & \\
\hline $50 \mathrm{~kg} \mathrm{~N} / \mathrm{ha} \mathrm{Ca}\left(\mathrm{NO}_{3}\right)_{2}$ & 40,0 & 6,0 & 42,3 & 4,6 & $+2,2$ & \\
\hline $100 \mathrm{~kg} \mathrm{~N} / \mathrm{ha} \mathrm{Ca}\left(\mathrm{NO}_{3}\right)_{2}$ & 45,1 & 11,1 & 50,0 & 12,3 & $+4,8$ & \\
\hline $150 \mathrm{~kg} \mathrm{~N} / \mathrm{ha} \mathrm{Ca}\left(\mathrm{NO}_{3}\right)_{2}$ & 53,2 & 19,2 & 55,0 & 17,4 & $+1,7$ & 5,1 \\
\hline $200 \mathrm{~kg} \mathrm{~N} / \mathrm{ha} \mathrm{Ca}\left(\mathrm{NO}_{3}\right)_{2}$ & 57,2 & 23,2 & 61,0 & 23,3 & $+3,7$ & \\
\hline $150 \mathrm{~kg} \mathrm{~N} /$ ha pétisó & 51,2 & 17,2 & 56,0 & 18,4 & $+4,8$ & \\
\hline $150 \mathrm{~kg} \mathrm{~N} / \mathrm{ha} \mathrm{Ca}\left(\mathrm{NO}_{3}\right)_{2}+$ & & & & & & \\
\hline $\begin{array}{l}60 \mathrm{~kg} \mathrm{P}_{2} \mathrm{O}_{5} / \text { ha } \\
\text { szuperfoszfát }\end{array}$ & 56,5 & 22,5 & 59,4 & 21,8 & $+2,9$ & \\
\hline $\begin{array}{c}150 \mathrm{~kg} \mathrm{~N} / \text { ha pétisó + } \\
60 \mathrm{~kg} \mathrm{P} \mathrm{O}_{5} / \mathrm{ha} \\
\text { szuperfoszfát }\end{array}$ & 56,7 & 22,6 & 61,2 & 23,6 & $+4,5$ & \\
\hline $\mathrm{SzD}_{5 \%}$ & 4 & & 4 & & 5,4 & \\
\hline Átlag & 49,2 & & 52,8 & & 3,5 & 3,8 \\
\hline$\%$ & 100 & & 107,3 & & 7,3 & \\
\hline
\end{tabular}

A kalcium-nitrát hatása erősen szignifikáns, az $\mathrm{N}$-adag növelése minden esetben további megbízható terméstöbbletet eredményezett. Hat év átlagában az $1 \mathrm{~kg} \mathrm{~N}$ hatására elért szénaterméstöbblet 19,2 kg volt. A $150 \mathrm{~kg} \mathrm{~N} /$ ha hatóanyagnak megfelelö kalciumnitrát és pétisó hatásában a föparcelláktól függően különbség mutatható ki. A meszezetlen főparcellákon az egyes években és az évek átlagában is a kalcium-nitrát jobbnak bizonyult, bár a szignifikancia határát nem éri el. Az eredményeket a fenológiai megfigyelések és a cönológiai elemzések is igazolták.

A $60 \mathrm{~kg} \mathrm{P}_{2} \mathrm{O}_{5}$ /ha hatóanyagnak megfelelő szuperfoszfát - a N-mütrágyákkal együtt alkalmazva - egy esetet kivéve jelentös ( $3-5$ t/ha) terméstöbbletet eredményezett. Ezek az eredmények arra utalnak, hogy az adott talajon optimális N-hatás csak a gyepnövényzet egyidejü P-ellátásával biztosítható.

Az 1 q szénatermés tápanyagigénye - a tápanyaghozam alapján számolva - a kezelések átlagában: $1,71 \mathrm{~kg} \mathrm{~N}, 0,54 \mathrm{~kg} \mathrm{P}_{2} \mathrm{O}_{5}, 2,64 \mathrm{~kg} \mathrm{~K}_{2} \mathrm{O}$, ill. 0,66 kg CaO. A N-mütrágyázás hatására a gyepnövényzet fajlagos tápanyagfelvétele a kontrollhoz viszonyítva a tápanyagoktól függően eltérö mértékben csökkent.

A különböző N-források hatékonyságának összehasonlítására ugyancsak szologyosodott szolonyec talajon, öntözött viszonyok között beállított kísérlet 4 éves eredményei 
alapján megállapítható, hogy a $150 \mathrm{q} / \mathrm{ha}$, ill. $15 \mathrm{q} / \mathrm{ha}$ mészkőpor hatása nem szignifikáns, bár a $150 \mathrm{q} /$ ha mészkőpor a kontrollhoz viszonyítva valamennyi esetben növelte a szénatermést. Az önmagában alkalmazott $60 \mathrm{~kg} \mathrm{P}_{2} \mathrm{O}_{5} /$ ha adagnak megfelelő szuperfoszfát az egyes föparcellákon belül és a föparcellák átlagában is megközelíti, de nem éri el a szignifikancia határát. A $150 \mathrm{~kg} \mathrm{~N} /$ ha hatóanyagnak megfelelő $\mathrm{N}$-trágyák valamennyi esetben $\sim 70 \%$-os terméstöbbletet biztosítottak. A korábbi kísérleti eredményeinkhez hasonlóan a kapott adatok azt igazolják, hogy az adott viszonyok között a felhasznált N-formák hatása azonosnak mondható (9. táblázat).

9. táblázat

A különböző N-mütrágyák hatása az ősgyep szénatermésére (t/ha) (86 \% szárazanyag, 4 év össz-termése) (Szologyosodott szolonyec, Palotás)

(LATKOVICSNÉ et al., 1972)

\begin{tabular}{|c|c|c|c|c|c|c|}
\hline Kezelés & $\begin{array}{c}\text { A } \\
\text { Kontroll }\end{array}$ & $\begin{array}{c}\text { B } \\
150 \text { q/ha } \\
\text { mészkö- } \\
\text { por }\end{array}$ & $\begin{array}{c}\text { C } \\
15 \text { q/ha } \\
\text { mészkőpor } \\
\text { első év }\end{array}$ & SzD $_{5 \%}$ & Átlag & $\%$ \\
\hline Kontroll & 19,1 & 21,5 & 19,2 & \multirow{9}{*}{3,6} & 19,9 & 100 \\
\hline $60 \mathrm{~kg} \mathrm{P}_{2} \mathrm{O}_{5} / \mathrm{ha}$ & 22,5 & 25,2 & 22,6 & & 23,5 & 117 \\
\hline $\begin{array}{l}60 \mathrm{~kg} \mathrm{P}_{2} \mathrm{O}_{5} / \mathrm{ha}+150 \mathrm{~kg} \\
\mathrm{~N} / \text { ha kalcium-nitrát }\end{array}$ & 34,3 & 35,7 & 32,0 & & 34,0 & 170 \\
\hline $\begin{array}{l}60 \mathrm{~kg} \mathrm{P}_{2} \mathrm{O}_{5} / \mathrm{ha}+150 \mathrm{~kg} \\
\mathrm{~N} / \text { ha pétisó }\end{array}$ & 33,1 & 34,9 & 33,7 & & 33,9 & 170 \\
\hline $\begin{array}{l}60 \mathrm{~kg} \mathrm{P}_{2} \mathrm{O}_{5} / \mathrm{ha}+150 \mathrm{~kg} \\
\mathrm{~N} / \text { ha ammónium-nitrát }\end{array}$ & 33,5 & 34,7 & 34,6 & & 34,2 & 171 \\
\hline $\begin{array}{l}60 \mathrm{~kg} \mathrm{P}_{2} \mathrm{O}_{5} / \mathrm{ha}+150 \mathrm{~kg} \\
\mathrm{~N} / \text { ha karbamid }\end{array}$ & 32,0 & 32,4 & 32,5 & & 32,3 & 162 \\
\hline $\mathrm{SzD}_{5 \%}$ & & 4,6 & & & 3,9 & 19 \\
\hline Átlag & 29,1 & 30,7 & 29,1 & & 29,6 & 148 \\
\hline$\%$ & 100,0 & 105,6 & 100,1 & & 101,9 & \\
\hline
\end{tabular}

\section{Összefoglaló értékelés}

A szikes talajok esetében jól érzékelhetők az egyes talajtulajdonságok és a növények víz- és tápanyagellátása közötti összefüggések. Jól jellemezhetők a szikesek pH-értéke, sótartalma, szervesanyag-tartalma stb. és a talajban lévő, ill. a talajba adott N-tápelem transzformációja és hatékonysága közötti összefüggések.

A közlemény a szikesek két fơtípusának - szoloncsák szolonyec, ill. szolonyec talajok különböző típusainak N-gazdálkodásával kapcsolatos kísérletek és vizsgálatok eredményeit foglalja össze. Más talajtípusokhoz hasonlóan a szikes talajok összes N-tartalma is szoros összefüggést mutat a talaj szervesanyag-tartalmával és a talajszelvényben történő elhelyezkedés mélységével. Az ásványi-N mennyiség (kicserélhető $\mathrm{NH}_{4}-\mathrm{N}$ és $\mathrm{NO}_{3}-\mathrm{N}$ ) talajtípusonként változó, a mélyben karbonátos kérges réti szolonyec talajon a felső talajrétegben az összes-N-tartalomnak $0,65 \%$-a, míg a mélyben humuszos rétegủ szolonyec réti talajon elérte az $1 \%$-ot. $\mathrm{A} \mathrm{NO}_{3}-\mathrm{N}$ mozgékonyságára utal a talajszelvényben a különböző szinteken eltérő mennyiségben megjelenő nitrát. A tavasszal és ősszel vett talajminták ásványi-N-tartalmában - $\mathrm{NO}_{3}-\mathrm{N}$-mennyiségében - megmutat- 
kozó különbségek a talajban végbemenő folyamatokra (ásványosodás, nitrifikáció, felfelé irányuló vízmozgás stb.) utalnak.

Érleléses modellkísérlet-sorozatban szoloncsákos szolonyec talajon kapott eredmények a N-forrás megválasztásának jelentőségét igazolták. Kalcium-nitrát alkalmazása során gázalakú $\mathrm{NH}_{3}$-veszteség nem volt kimutatható, míg az ammónium-szulfát kezelésben a kísérlet befejezésekor a veszteség elérte az adott $\mathrm{N}$-mennyiség több, mint felét. A magas $\mathrm{pH}$ és sókoncentráció gátolta a nitrifikáló baktériumok tevékenységét, ennek következtében a $\mathrm{NO}_{3}-\mathrm{N}$ mennyisége elenyésző volt. Optimális nedvesség- és hömérsékleti viszonyok között a karbamid hidrolízise gyorsan végbement és a transzformáció során keletkezett $\mathrm{NH}_{4}-\mathrm{N}$-mennyiség csökkenésével arányosan nőtt a gázalakú $\mathrm{NH}_{3}$-veszteség, amely a kísérlet befejezésekor elérte az adott $\mathrm{N}$-mennyiség 74,7 \%-át. $\mathrm{A} \mathrm{NO}_{3}-\mathrm{N}$ tartalom a nitrifikációs folyamat gátlásával összefüggően mindvégig elenyésző volt.

A két jellegzetes szikes talajon - szoloncsák és gyengén szologyosodott sztyeppesedő réti szolonyec talaj - eltérỏ volt az ásványosodás mértéke, a nitrifikáció során képződött $\mathrm{NO}_{3}-\mathrm{N}$ mennyisége, ill. az ammónium-nitrát transzformációja során képződött ásványi-N komponenseinek $\left(\mathrm{NH}_{4}-\mathrm{N}\right.$ és $\left.\mathrm{NO}_{3}-\mathrm{N}\right)$ mennyisége és egymáshoz viszonyított aránya.

A korábbi eredményekhez hasonlóan szoloncsákos talajon kifejezetten megmutatkozott a nitrifikációt gátló tényezők hatása a $\mathrm{NO}_{3}-\mathrm{N}$-képződésre ill. a $\mathrm{NH}_{3}$-veszteségre.

$\mathrm{A}{ }^{15} \mathrm{~N}$-jelzett szerves anyag ásványosodásának üteme és mértéke, a mineralizáció során képződött $\mathrm{NH}_{4}-\mathrm{N}$ és $\mathrm{NO}_{3}-\mathrm{N}$ mennyisége a két szikes talajon szintén eltérő volt. A gyengén szologyosodott sztyeppesedő réti szolonyec talaj a szoloncsákos talajnál kedvezőbb feltételeket biztosított a szerves anyag ásványosodásához és a képződött $\mathrm{NH}_{4}-\mathrm{N}$ nitrifikációjához.

A ${ }^{15} \mathrm{~N}$-jelzett szerves anyaggal együtt adott ammónium-nitrát kedvezően befolyásolta a szerves anyag lebontását. A talajok ásványi-N mennyiségének változása összefüggést mutatott a nitrogén mobilizációs-immobilizációs folyamataival, a talajban végbemenő változásaival ( $\mathrm{NH}_{4}-\mathrm{N}$ lekötődés, $\mathrm{NH}_{3}$-veszteség stb.).

A szikes talajok $\mathrm{N}$-ellátottságával, a $\mathrm{N}$-tápelem dinamikájával szorosan összefügg a N-trágyázás hatékonysága. Karbonátos szoloncsákos szolonyec, ill. szologyosodott szolonyec talajjal beállított kísérletben a fiatal búza- és kukoricanövények a mag tartaléktápanyagainak felhasználásával egy időben a talajban rendelkezésre álló $\mathrm{N}$-tápelemet is hasznosították a N-formáktól, talajtól, növényfajtól függően eltérő mértékben.

A „talajbank” talajaival beállított közös tenyészedény-kísérlet sorozatból kiemelt három szikes talajjal végzett kísérletünkben lehetöség adódott a ${ }^{15} \mathrm{~N}$-jelzett ammóniumnitrát átalakulási folyamatainak nyomon követésére a talajban és az angolperje által történő hasznosulásának jellemzésére a szikesek természetes tápelem-ellátottsága mellett.

A különböző szolonyec típusú talajokon az angolperje szárazanyaghozama és a kivont $\mathrm{N}$-mennyiség a talajtípustól függően változott. $\mathrm{A}{ }^{15} \mathrm{~N}$-trágyából származó $\mathrm{N}$ részarány a hat vágás átlagában lényegében azonos volt, az összes-N-mennyiség több mint 80 \%-a származott az ammónium-nitrátból. A tenyészidő alatt (138 nap) az összes kijuttatott N-mennyiség 28,5-36,9 \%-át hasznosították a növények. Ezek a vártnál alacsonyabb hasznosulási értékek arra utalnak, hogy az optimális vízellátás mellett a szikes talajok kedvezötlen tulajdonságai ill. az egyes tápelemek hiánya, esetleg túlsúlya is befolyásolta a N-mütrágya hatékonyságát.

A szolonyec talajok N-ellátottságát jellemző adatok eltérőek - az összes-N, ásványi$\mathrm{N}$, kötött $\mathrm{NH}_{4}-\mathrm{N}$ - és összefüggésben állnak a talajtípusok ismert tulajdonságait kifejező 
paraméterekkel. A kísérlet befejezése utáni talajvizsgálat eredményei a talajban maradt trágya-N és a növény $\mathrm{N}$-felvétele közötti szoros összefüggésre utal.

A N-trágyázás hatására nőtt a szikes talajok összes-N mennyisége. Ásványi-N-tartalmuk elérte összes- $\mathrm{N}$-tartalmuk 11,2-15,7 \%-át. Az $\mathrm{NH}_{4}-\mathrm{N}$ és $\mathrm{NO}_{3}-\mathrm{N}$ mennyisége, ill. a kötött $\mathrm{NH}_{4}-\mathrm{N}$-tartalom a szikesek jellemző tulajdonságaival megegyezően változott.

A hónapokig tartó kísérletben a legkisebb (3\%) N-veszteséget a kedvezőbb tulajdonságokkal rendelkező mélyben szolonyeces csernozjom talajon mértük, míg az alacsony $\mathrm{pH}$-jú, rossz vízgazdálkodású réti szolonyec, ill. sztyeppesedő réti szolonyec talajon a N-veszteség - feltehetően a denitrifikációs folyamatok hatására - elérte a 21 $25 \%$-ot.

A szikes talajok ésszerü hasznosításának egyik leggazdaságosabb formája rét-legelöként történő használata. Megfelelő agrotechnika alkalmazásával kedvezőtlen víz- és tápelem-gazdálkodásuk bizonyos mértékig javítható. A több évtizedes kísérleti eredmények és gyakorlati tapasztalatok a klasszikus szikjavítás mellett az öntözés és trágyázás kedvező hatását is bizonyítják. Szologyosodott szolonyec talajon lévő ősgyepen az öntözés hatására az értékesebb füfajok, ill. pillangósok elötérbe kerülésével a talaj természetes tápelemtartalékainak mobilizálásával, ill. a növény optimális vízellátásának biztosításával a szikes területek produktivitása jelentősen növelhető.

Öntözés mellett a kalcium-nitrát, a különböző N-mütrágyák alkalmazása, ill. a kora tavaszi N-fejtrágyázás jelentős szénaterméstöbbletet eredményeztek. A meszezés hatása a kísérletben megközelítette a szignifikancia határát. Ugyanakkor bizonyított, hogy szikes legelőkön a N-hatás a gyepnövényzet egyidejü optimális P-ellátásával biztosítható.

\section{Irodalom}

A szikes talajok hasznosításának és javításának módszerei. (Ankét, Szeged, 1965. május 28.), 1966. MTA IV. Oszt. Közlem. 25. 1-180.

ÁBRAHÁM L. \& BOCSKAI J., 1971. Szikes talajaink hasznosítása és javítása. OMMI. Budapest.

BLASKó L., 1999. A réti szolonyec talajok javításának tartamhatása. Agrokémia és Talajtan. 48. $517-529$.

BoDROGKÖZI Gy., 1964. A besenyszögi szikhasznosítási és tápanyagadagolási kísérletek első évi eredményeinek synökológia értékelése. Agrokémia és Talajtan. 13. 85-100.

International Sympoium on Sustainable Management of Salt Affected Soils in the Arid Ecosystem (Cairo, Egypt, 22-26 Sept, 1977). Abstracts Volume. ISSS-University of Ain Shams, Cairo.

LATKOVICS, I., 1965. Vlijanie azotoszoderzsascsih vescsesztv na effektivnoszty melioracii szoloncov vengerszkoj nizmennoszti. Agrokémia és Talajtan. 14. (Suppl.) 341-344.

LATKOVICS GY-NÉ, 1966. Kalcium- és nitrogéntartalmú javítóanyagok kisadagú alkalmazása öntözött szikes gyepen. III. A kísérletek második évi eredményei. Agrokémia és Talajtan. 15. $51-60$.

LATKOVICS, I., 1974a. Vlijanie orosenija i azota na urozsaj szena na oszologyelom szolonce. Trudi X. Mezsdunarodnogo Kongressza pocsvovedov. IV. 121-129. Izdatelsztvo Nauka.

LATKOVICS GY-NÉ, 1974b. Nitrogénmütrágyák hatásának vizsgálata ${ }^{15} \mathrm{~N}$ indikációval szikes talajon. Agrokémia és Talajtan. 23. 11-20.

LATKOVICS, I., 1977. Modern methods of application of fertilizers with particular regard to salinity and alkalinity conditions. Proc. Indo-Hungarian Seminar on Management of Salt Affected Soils, Febr 7-12, 1977. 194-201. Central Soil Salinity Research Institute. Karnal.

LATKOVICS GY-NÉ, 1980. Az intenzív mütrágyázás hatása a talaj termékenységére. Ankét, 1979. okt. 29. MTA TAKI. Budapest. 37-71. 
LATKOVICS GY-NÉ, 1981. A nitrogénműtrágya transzformációjának és a szerves N mineralizációjának tanulmányozása ${ }^{15} \mathrm{~N}$ stabil izotópjelzéssel. III. A N-formák átalakulása két szikes talajon. Agrokémia és Talajtan. 30. 273-290.

LATKOVICS GY-NÉ, 1982. A nitrogén átalakulása és mozgása a talajban. Doktori disszertáció.

LATKOVICS GY-NÉ, 1991. X. Mütrágyázási Világkongresszus, Nicosia, Cyprus, 1990. október 2127. Agrokémia és Talajtan. 40. 339-350.

LATKOVICS, I. \& MÁTÉ, F., 1968. Investigations Izucsenie pri pomoscsi izotopa N-15 effektivnoszti mocsevini kak udobrenija. Zeszyty Problemowe Postepos Nauk Rolniczych Zeszyt. 34. 373-380.

LATKOVICS GY-NÉ \& Szabolcs I., 1980. A Nemzetközi Mütrágyázási Központ (CIEC) és a Garyounia Egyetem Szimpóziuma, Benghazi, 1979. november 26-december 1. Agrokémia és Talajtan. 29. 353-360.

LATKOVICS GY-NÉ \& VARGA GY., 1971. A fiatal kukoricanövények ammónium- és nitrát-nitrogén felvételének vizsgálata ${ }^{15} \mathrm{~N}$ indikációval. Agrokémia és Talajtan. 20. 559-565.

LATKOVICS GY-NÉ, MÁTÉ F. \& SARKADI J., 1972. A kalcium-nitrát mütrágya. Agrokémia és Talajtan Kiskönyvtára. 3. Budapest.

MÁTÉ, F. \& LATKOVICS, I., 1963. Rezultati primenenija szposzoba mecsenih atomov pri izucsenii metoda iszpolszovanija azotnih udobrenij rasztenijami. Zeszyty Problemowe Postepos. Nauk Rolniczych Zeszyt. 34. 213-224.

MeNGEL, K., 1976. A növények táplálkozása és anyagcseréje. Mezőgazdasági Kiadó. Budapest.

NÉMETH T., 1996. Talajaink szervesanyag-tartalma és nitrogénforgalma. MTA Talajtani és Agrokémiai Kutató Intézete. Budapest.

SARKADi J., LATKOViCs GY-NÉ \& MÁTÉ F., 1969. A karbamid mint műtrágya. Agrokémia és Talajtan Kiskönyvtára. 1. Budapest.

StefanOvits P., 1981. Talajtan. Mezőgazdasági Kiadó. Budapest.

SzABOLCS I., 1954. A Hortobágy talajai. Mezőgazdasági Kiadó. Budapest.

SZABOLCS, I., 1974. Salt Affected Soils in Europe. Martinus-Nijhoff -The Hague and Research Institute for Soil Science and Agricultural Chemistry of the Hungarian Academy of Sciences, Budapest.

SzABOLCS, I. \& LATKOVICS, I., 1967. The effect of various nitrogen fertilizers on the mineral nutrition of winter wheat studied on two different types of salt affected soils. In: Proc. Symp. III. Isotopes in Plant Nutrition and Physiology, Vienna, 5-9 Sept, 1966. 3-11. IAEA/FAO. Vienna.

VÁRAllyay Gy., 1999. Szikesedési folyamatok a Kárpát-medencében. Agrokémia és Talajtan. 48. 399-418.

Érkezett: 2000. december 6. 